\title{
A Bloody Solidarity: Nguyen Thai Binh and the Vietnamese Antiwar Movement in the Long Sixties
}

Ann Tran 


\section{Abstract}

This paper uncovers the history of antiwar activist Nguyen Thai Binh and the birth of the Union of Vietnamese after his death. As a former student at the University of Washington, Seattle, Binh participated in numerous antiwar protests against the U.S. military and imperialist government. On July 2, 1972, he hijacked Pan Am Flight 841 headed to Tan Son Nhut airport to protest American bombings of North Vietnam, but was assassinated in the attempt. Amidst the broiling anti-war movements of the 1960s and early 1970s, the Union of Vietnamese was the only group of Vietnamese in America to organize against the war following Binh's death, suggesting the unique positionality of Vietnamese students and early immigrants among other marginalized groups in their struggles for liberation. In this paper, I reference the works of scholars Karen Ishizuka and Sylvia Shin Huey Chong to compare different methodological approaches to writing about the Asian American antiwar movement. Their texts frame my discussions of the invisibility of the Vietnamese antiwar narrative, the cross-cultural alliances that formed from political convergences, and the orientalist perception of the Vietnamese body. Thus, I argue that Nguyen Thai Binh's activism and the Union of Vietnamese demonstrate a departure from the predominantly non-Vietnamese antiwar historiography. Through my analysis of letters, pamphlets, and government documents, I consider the ways in which Binh's fatal devotion to ending American brutality in Vietnam and the Vietnamese antiwar movement both challenge American perceptions of race and ethnicity and critique the violent militarism of the war in Vietnam.

On an early summer morning in 1972, a young Vietnamese student named Nguyen Thai Binh boarded a flight from Hawaii to Saigon. Before departing, he quickly transcribed a letter to Nguyen Huu An, a close friend and one of the last people to receive correspondence from him. Binh wrote, "Morning. Day of action. On the flight from Hawaii. . . For me, success or failure, life or death will be known within a few hours. However difficult our way is, I still believe that peace, and independence will return to our Vietnamese people and our country." ${ }^{1}$ Days later, newspapers across the United States would describe him as a slain hijacker, obscuring his name with slanderous epithets. Haphazardly thrown onto the tarmac of a landing field after catching merciless rounds of gunfire, Binh's lifeless body quickly became a rallying symbol for resistance against United States militarism.

Nguyen Thai Binh, an antiwar dissident and a former student at the University of Washington, Seattle, hijacked Pan Am World Airways Flight 841 on July 2, 1972, in what he described as "an act of revenge" for the American bombing of North Vietnam. ${ }^{2}$ The flight departing from San Francisco carried 153 passengers, and was destined for Saigon with stops in Honolulu, Guam, and Manila. Forty-five minutes after the jet left Manila for Saigon, Binh coerced a stewardess to carry a note to the captain of the flight, demanding that he divert the plane to Hanoi where the aircraft would be destroyed to thwart its use for further war-related purposes. Binh threatened to blow up the plane with explosives if his demands were not met. Captain Gene Vaughn ignored the initial note, calling it a hoax, but paid

\footnotetext{
${ }^{1}$ Nguyen Thai Binh to Nguyen Huu An, Jul 3, 1972, Accession no. 2242-001, Binh Memorial Collection, Pacific Northwest Historical Documents, Special Collections Libraries, University of Washington.

${ }^{2}$ While July 2, 1972 was the official date of Binh's death in the United States, he died in Vietnam on July 3, 1972. This accounts for the twelve-hour time difference between the date he left Hawaii for Vietnam and the record of his death in American newspapers.
} 
attention when the second one, stained with Binh's blood, arrived in the cockpit declaring, "This indicates how serious I am about being taken to Hanoi." Still, the Captain did not heed Binh's command. When the plane landed at Tan Son Nhut Aiport, under the pretense of a refueling stop, Captain Vaughn approached the young hijacker and pinned him to the ground with the help of two other passengers. One of those passengers was W.H. Mills, a retired San Francisco area policeman on his way to Vietnam to work under an American firm. Earlier, Vaughn had taken possession of Mills's firearm for safekeeping. He now returned the weapon to the officer and urged him to "Kill that son of a bitch!” Mills then shot Binh in the chest five times. Following Binh's death, Captain Vaughn threw Binh's body "out of that aircraft like a football," leaving the corpse on the tarmac. ${ }^{3}$

Binh's dramatic and eventually fatal attempt to hijack the Boeing 747 plane evinces the passion he had to resist what he deemed an immoral and barbaric war. Firmly affixed upon his desire for peace in Vietnam, he dedicated a significant portion of his time as a university student in Washington to demonstrations against the U.S. government and military's operation in Vietnam. Like other disillusioned students in the antiwar movement, Binh attended rallies and sit-ins to help bring attention to the immorality of U.S. involvement in Vietnam. Unlike the others, who occupied buildings across college campuses and burned down ROTC buildings, he took a more unconventional route by hijacking a passenger plane headed to Saigon. Unlike other radical activities of antiwar groups at the time, Binh's story has been surprisingly absent from historical accounts. Covered in only a smattering of academic articles, the lack of scholarly attention gestures to the broadly dismissed narratives of Vietnamese activists during the war. Their exclusion from America's antiwar history and, distinctively, from the inchoate Asian American movement that formed after the U.S. intervention in the 1960s, demonstrates a gap in our understanding of crucial perspectives from those directly and personally affected by the conflict. The unique positionality of Vietnamese students in America during the highly controversial war provides historians a compelling glimpse into the American public's attitudes and reactions toward the presence of the perceived foreign enemy on the home front.

In the years following the Vietnam War, scholars have examined various antiwar histories and prominent figures in the United States, including the Vietnam Veterans Against the War (VVAW), Women Against the War, college student protests, and Chicanx/Black resistance movements. These histories have illuminated the American public on the costly and untainted versions of war that are often omitted from common history books. Yet, the absent history of Vietnamese students in America during this time, particularly those in opposition to the war, is a significant omission because of its erasure of central figures to the war's history. Not only did the Vietnamese students collaborate with other antiwar groups to advance a racial-political agenda, they also contributed to the knowledge formation of Third World liberation movements at the time.

While there exists a tendency to conflate Vietnamese students in America with Asian Americans who were becoming more politically conscious during the war, I argue that a justifiable distinction exists between both groups. The Asian American movement, backed by mainly Chinese, Filipino, Korean, and Japanese Americans, stressed a racial similarity between the Vietnamese in Vietnam and American

${ }^{3}$ Paul L. Montgomery, "Hijacker Killed in Saigon; Tried to Divert Jet to Hanoi,” The New York Times, Jul 3, 1972. 
Asians. Unlike Asian Americans, who in that period had been in the United States for a long time, Vietnamese students had a deeper attachment to their homeland than they did to America. They sought not equal representation on U.S. soil but liberation of their homeland from Western oppressors, whom they viewed to be the former French colonizers and the new American invaders. Imbued with Western educational values but rooted within their ancestral Vietnamese traditions, they used the tools embodied by other antiwar activists to rally for the survival and safety of their Vietnamese friends and families back home. The students' intimate connection to Vietnam exacerbated the turmoil and anger they felt when bombs obliterated the villages of their homeland. Unlike other groups who saw the war as another demonstration of America's mistreatment of people of color and collectivized to demand freedoms, Vietnamese students protested the war for Vietnam's self-determination and for the protection of their countrymen against the increasingly destructive use of American firepower. While not all Vietnamese students rallied against the war, those who did risked imprisonment, deportation, and even death.

In this paper, I build upon the works of scholars Karen Ishizuka and Sylvia Shin Huey Chong to compare different methodological approaches to writing about the Asian American antiwar movement. Their texts frame my discussions of the invisibility of the Vietnamese antiwar narrative, the cross-cultural alliances that formed from political convergences, and the orientalist perception of the Vietnamese body. Thus, I argue that Nguyen Thai Binh's activism and the development of Vietnamese antiwar groups demonstrate a departure from the predominantly non-Vietnamese antiwar historiography. Through my analysis of letters, pamphlets, and government documents, I consider the ways in which Binh's fatal devotion to ending American brutality in Vietnam and the Vietnamese antiwar movement both challenge American perceptions of race and ethnicity and critique the violent militarism of the war in Vietnam.

\section{The Asian American Antiwar Movement}

The violence, bloodshed, and political upheavals of the Vietnam War era spawned a number of significant social movements within the United States in the 1960s and 1970s. From women's liberation to the Black Power movement, the emergence of radical leftist groups during the war ignited the nation's consciousness on issues of gender inequality, racial injustice, and underrepresentation. To fully understand how Vietnamese students' voices both supported and challenged the existing dialogue on race at the time, I examine how the Asian American antiwar movement, which emerged in reaction to the war's racist treatment of Asian bodies, granted greater awareness to minority representation and imparted critical consciousness on issues of race and identity across the nation.

The birth of the Asian American movement in the 1960s significantly unified Americans of Asian descent in the collective struggle for representation alongside other marginalized groups. As these activists and protesters spoke out against the U.S. war in Vietnam, connecting their fight for equality with Southeast Asians in the decolonizing Third World, they began to disassemble the racialized depictions of Asians in the West. In The Oriental Obscene and Serve the People, respectively, film scholar Sylvia Shin Huey Chong and historian Karen Ishizuka describe the gradual deconstruction of denigrating stereotypes by providing examples of Asian American activists who refused to fit passively into the "model minority" 
mold. Drawing upon the critical framework of orientalism established by cultural theorist Edward Said, Chong and Ishizuka analyze the racialized experiences of Asian Americans before and during the war, helping us to reconceptualize how race and violence play significant roles in radical formations. While each scholar uses her own specialized methodologies to critique the racial politics of the American war in Vietnam, they both complicate the orientalist structure of the West by reframing how Asian Americans employed their status as the "other" to collectivize and identify with the larger Asian struggle against American imperialism.

Chong and Ishizuka contextualize their critical analyses of the antiwar movement with historical grounding in the birth of Asian America. In Serve the People, Ishizuka uncovers the genesis of the Asian American movement by alluding back to the history of Chinese, Filipino, and Japanese immigrants in the late 1800s and early 1900s. The passage of racist immigration laws in the twentieth century stigmatized Asian immigrants as foreigners who were wanted for their cheap labor, but unwanted in society because of their racial difference. In response to overwhelming white protests to Asians "taking" desirable jobs, the U.S. government placed discriminatory restrictions on Asian immigration. Racist propaganda simultaneously painted Chinese, Japanese, and Filipino Americans as "Orientals" who were "weak and suitable for colonization." Asians in America during the Vietnam War empathized with the overseas Vietnamese who endured a similar form of racial subjugation through their derogatory branding as "gooks." According to Chong, the political collectivity of Asian America came into being as a response to American orientalism. Essentially, "racism against Asian immigrants and their descendants [marked] them as unassimilable and essentially foreign, and the effects of American neocolonialist militarism abroad. . . . associated Asians in America with larger Asian diasporic communities. ${ }^{95}$ Ishizuka echoes this sentiment, addressing the role in which "oppositional consciousness" in the new Asian American movement empowered and defined Americans of Asian descent as more than the simplified and derogatory term, "Orientals." 6

Ishizuka inserts the narratives of numerous subjects to highlight notable contributors in the Asian American antiwar movement, from activist Chris Iijima to photographer Bob Nakamura. Her focus on personal narratives illustrates the centrality of experience in activist histories, particularly as the Asian American movement formed out of a cluster of dissimilar yet impassioned people. Her consistent use of the possessive "we" when referring to the Asian American movement affirms this unified history in which she shares a common past. ${ }^{7}$ Unlike Ishizuka, who bases her historical analysis of the Asian American movement on both experiential evidence and interviews, Chong approaches the concept of orientalism and antiwar narratives through a psychoanalytic lens. American reactions to visual representations of the war produced what she calls the "oriental obscene," defined as the "phantasmatic, visual presence that dominates the American cultural imaginary in the absence of an Asian American political collectivity that can speak for itself." Her analysis of famous photographs from the war-Saigon "Execution"

\footnotetext{
${ }^{4}$ Karen L. Ishizuka, Serve the People: Making Asian America in the Long Sixties (London: Verso, 2016), 16.

${ }^{5}$ Sylvia Shin Huey Chong. The Oriental Obscene: Violence and Racial Fantasies in the Vietnam Era (Durham: Duke University Press, 2012$), 19$.

${ }^{6}$ Ishizuka, Serve the People, 62.

${ }^{7}$ Ishizuka, Serve the People, 60.

${ }^{8}$ Chong, The Oriental Obscene, 21.
} 
(1968), the My Lai Massacre images (1969), and "Napalm Girl" (1972)—reframes the Asian body as a space for racialized fantasies. Although obscene in their graphic nature, these images aroused the American conscience upon their release to the public. Viewers' discomfort from these images has led to the modern censorship of war photographs depicting the dead. Only when the injured or dead subjects are American soldiers maimed at the hands of foreign perpetrators are these images left uncensored. ${ }^{9}$ However, the problematic depiction of violence on Asian bodies has only perpetuated in other forms, from graphic war movies like Deer Hunter to the American martial arts craze in the 1970s. Thus, as Chong argues, Americans continue to incite violence on Asian bodies through racialized fantasies found within cultural productions.

Chong and Ishizuka offer similar analyses of the motivations behind the Asian American antiwar campaign and the factors that influenced its growth. Like the mainstream antiwar movement which stressed the imperialist nature of the war in Vietnam, Ishizuka argues that the Asian American movement formed out of the need to address the war's racist underpinnings. ${ }^{10}$ Sharing similar backgrounds as marginalized minorities in America, Black and Brown activists formed alliances with the budding Asian American coalition to fight back against U.S. militarism. In particular, the Black antiwar movement influenced Asian American organizing around opposition to the Vietnam War by connecting African American racial struggles with the dehumanizing conditions in Asian communities. Asian American groups adapted the popular phrase "No Vietnamese Ever Called Me Nigger!" onto placards that read: "No Vietnamese Ever Called Me Chink" and "No Vietnamese Ever Called Me Jap." 11 The encompassing grievances that largely defined historical struggles faced by blacks and Asians led Chong to investigate the organic formation of Afro-Asian alliances during the war. As Chong argues, many blacks opposed the war because they felt the violence against the Vietnamese was a direct extension of the violence against blacks in the United States, a shared oppression borne out of racism. Thus, the black antiwar movement used "the abuses of the Vietnam War to stage a larger critique of white racism and gesture toward a Third World internationalism that aligns American blacks with the Vietnamese as brothers in a common struggle." ${ }^{12}$ By incorporating the history of black and Asian alliances during the antiwar movement, Chong and Ishizuka reimagine how racial differences, though often divisive, can act as tools to help marginalized communities consolidate against a common threat.

Against the burgeoning waves of protests led by student groups in the late 1960s, the antiwar activities of South Vietnamese students in the United States registered barely a blip on the radar. In comparison to the widespread attention and historical acknowledgment given to the Asian American antiwar movement, accounts of Vietnamese student activities are largely absent, which excludes crucial non-American perspectives from public memory. Scholars have not extensively studied the involvement of Vietnamese students in America during the war despite their roles in its history. Likewise, both Chong and Ishizuka acknowledge the near invisibility of the Vietnamese in the antiwar movement in their respective texts. Despite the Asian American identification with the Vietnamese struggle for

\footnotetext{
${ }^{9}$ Ibid., 126.

${ }^{10}$ Ishizuka, Serve the People, 100.

${ }^{11}$ Ishizuka, Serve the People, 100.

${ }^{12}$ Chong, The Oriental Obscene, 68.
} 
independence from the white oppressor, the Vietnamese themselves were not major players in the panAsian coalition. ${ }^{13}$ Their absence stems from the low number of Vietnamese in America during the war. In fact, only 30,000 Vietnamese dwelled in the United States by 1975, or about two percent of the total Asian American population. The majority of Vietnamese in America were either diplomats or students who did not participate in the antiwar movement. ${ }^{14}$ Nguyen Thai Binh and a few others, however, were the exception. Both Chong and Ishizuka cite Binh's antiwar activities as a radical deviation from the apolitical conformism within Vietnamese communities. In a brief endnote, Chong details Binh's participation in a sit-in demonstration with nine other Vietnamese students at a South Vietnamese consulate in New York on February 10, 1972. ${ }^{15}$ Ishizuka stresses this unusual narrative by providing more information on Binh's hijacking mission and posthumous legacy. His eventual murder fueled an eruption in Vietnamese activism, resulting in the formation of youth brigades that rallied against the increasing brutalities committed by the U.S. military on Vietnamese bodies. The commemorations held in Binh's honor, from youth demonstrations to memorial ceremonies held annually at the University of Washington for nine years, illustrate the deep impact Binh made on the Asian American community at large. ${ }^{16}$

Despite the low number of Vietnamese activists in the antiwar movement, the American War in Vietnam inadvertently fostered a pan-Asian coalition in the United States. The Asian American movement that followed drew upon the concerns of the entire group to raise both political and racial consciousness. The multi-issue movement inverted the orientalist structure established in postcolonial theory by identifying "otherness" as a common ground for Asian Americans and Southeast Asians to unify in the struggle for freedom and equality. Additionally, the collectivization of Asian Americans renewed their interest in historical grievances that once subjugated specific groups of Asians in the United States and influenced the formation of group alliances across racial and ethnic divides. Together, Chong and Ishizuka insert missing narratives into the American anti-war movement by depicting the roles Asian Americans played alongside activists of color from more publicized movements. Their analyses of important figures in the movement and the racialized fantasies rooted within American reactions to the obscene allow us to understand and reimagine how Asian Americans negotiated issues of race and violence during a turbulent period in U.S. history.

\section{The Conversion of Pro-American South Vietnamese Students}

According to an account given in 1972 by Maurice J. Williams, the deputy administrator of the United States Agency for International Development (USAID), the number of South Vietnamese students in the United States steadily increased after 1957. In agreement with successive South Vietnamese governments, the United States trained more than 3,703 students in various state universities at a cost estimated to be $\$ 18$ million. The Saigon government selected students with a working command of English and expected them to return home and help in national development after their studies. ${ }^{17}$

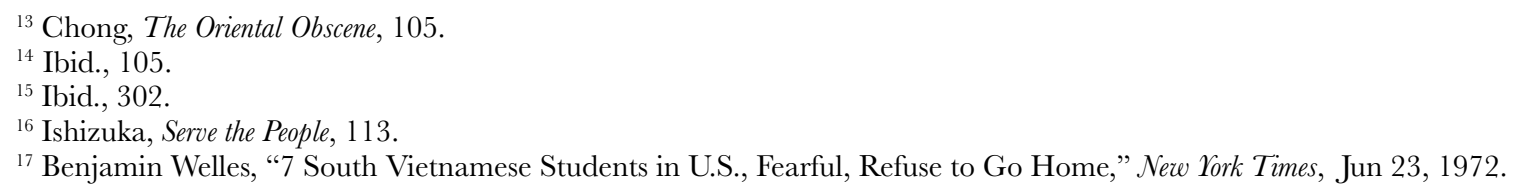




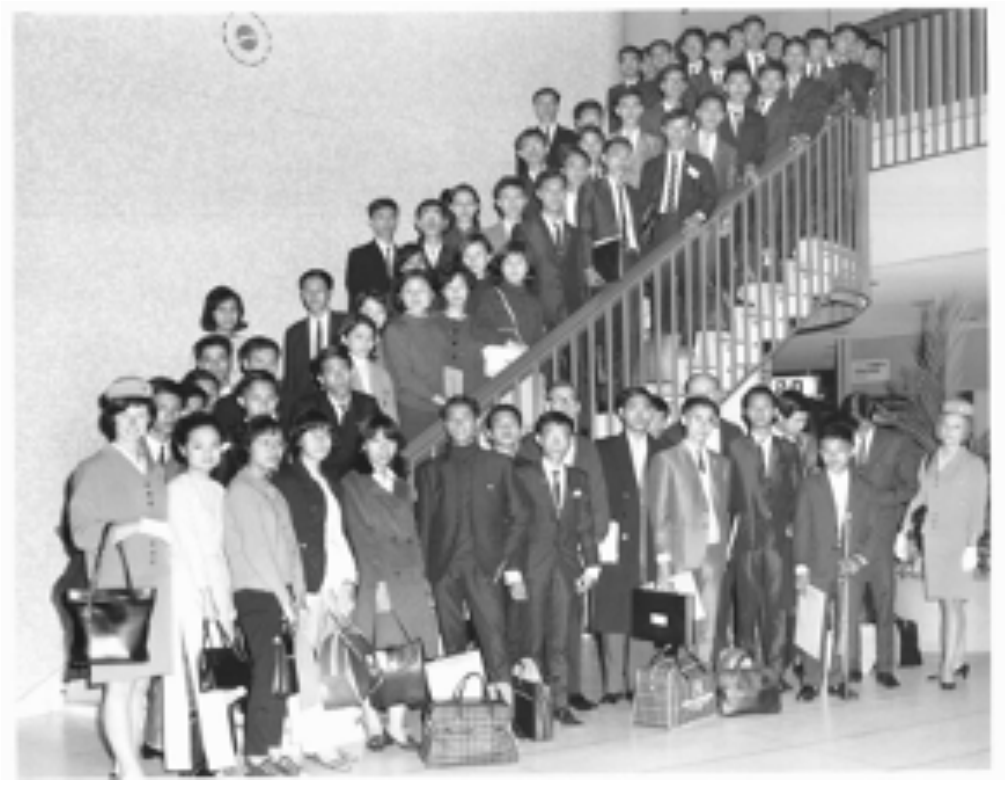

Figure 1. Vietnamese exchange students, including Nguyen Thai Binh, study abroad with USAID Leadership Scholarships. Source: Leadership Scholarship Organization.

However, some students refused to return home after their studies, fearing the Saigon government's prosecution for their antiwar activities in the United States. While not all students fulfilled this duty, those who protested the conflict bore the psychological burden of negotiating between their responsibilities as Vietnamese citizens and their personal convictions as peace advocates in America.

The Leadership Scholarship was a formal scholarship sponsored by USAID that enabled hundreds of South Vietnamese students to study in the United States. USAID was primarily responsible for assisting with U.S. counterinsurgency efforts and later the Vietnamization policy in South Vietnam. Thus, the Leadership Scholarship aimed to promote nation-building in the country. The program began in 1967 and lasted until 1970. The first group of sixty-one students were granted scholarships for four years, and three subsequent groups of students arrived in the United States thereafter. The first group arrived in San Dimas, the second in Pacific Palisades, the third in Asilomar, and the fourth at Claremont College, California. After several days of orientation, students moved into smaller groups before they transitioned to their assigned school among the Cal State Colleges and Universities. Individual students could later move to a different university if they desired to do so. ${ }^{18}$ The concentration of participants in the West Coast, and specifically in California, was the result of a contract signed by the USAID and a group of California State Colleges that agreed to host recipients of the Leadership Scholarships. In return, the agency covered their arrivals and expenses. ${ }^{19}$

Each group of Vietnamese students selected by USAID came for different purposes and lengths of time. USAID Group I included mostly personnel from the Army of the Republic of Vietnam (ARVN),

\footnotetext{
18 "Leadership Students," http://www.leadershipstudents.org/Relatives/faq.htm.

${ }^{19}$ Nguyet Nguyen, “Antiwar Transnationalism: People's Diplomacy in the Vietnam War," PhD diss., (American University, 2019).
} 
and Group II were selected on the basis of academic achievement and leadership capacity. Nguyen Thai Binh was a member of USAID Group II. The Leadership Scholarship application process was more selective for the second group of arrivals because of the Saigon government's rigorous assessments of the candidates' qualities. The Saigon Ministry of Education established requirements for this process and administered high school exams to place students into four categories based on their test results. All students selected for the scholarship were chosen from the highest scoring group, called "distinction," or the group immediately below them. They were also measured on "leadership capacity," which included judgments on their previous extracurricular activities and their ability to contribute back to South Vietnamese society following their return from the United States. The Ministry of Education then investigated their backgrounds before providing them security clearance. After this competitive process, the students met with USAID representatives for one final interview before entering an essay-writing contest hosted by a joint Vietnamese and American committee. Students chosen from this selective group were the finalists of their cohort. The Ministry of Education then approved them for traveling and sent their names to USAID for final logistics. The long and difficult selection process in which these students partook cannot be understated. It is no wonder, then, that out of a group of more than one hundred students who qualified for "distinction," only 61 students joined the first Leadership Scholarship group. ${ }^{20}$

According to historian Ngo Vinh Long, who was one of the students selected to study in the United States, those under USAID scholarships had to agree to fulfill obligations when they returned to South Vietnam. These obligations could be for five to ten years and entailed filling positions sponsored by the Saigon government or the American embassy. If any student spoke ill of the war or either government during their time in the United States, they were subject to interrogation and deportation. ${ }^{21}$

Prior to arriving in the United States, all participants held neutral opinions of the war and were not committed to Communism or the National Liberation Front (NLF). Vietnamese students who came to America were from conservative families or affiliated with the government, and therefore, had previously never expressed their opinions on the war or the realities of life in Vietnam. ${ }^{22}$ Furthermore, most students were unaware of the broader implications of the conflict and knew little concerning the policies and military movements in their own country. As urbanites insulated within South Vietnam's repressive influence, they were primarily concerned with studying to attain a scholarship abroad, and had little political consciousness. ${ }^{23}$

This neutrality, however, changed significantly after the students' arrival in the United States. A set of interviews conducted by historian Nguyet Nguyen reveals that most students attest the shift in their political and ideological beliefs to the influence of American activists and media. Nation-wide demonstrations were particularly effective in the students' conversion process because college students across multiple campuses, veterans, and minority groups were gaining momentum in their protests against the war's violence in the late 1960s. In addition, the March 1968 assassination of Martin Luther King Jr. amplified internal debates on campuses surrounding the United States' ongoing racial divide,

\footnotetext{
${ }^{20}$ Nguyet Nguyen, "Antiwar Transnationalism."

${ }^{21}$ Ngo Vinh Long, "Vietnamese students and the center," Bulletin of Concerned Asian Scholars, vol. 3, no. 2 (1971): 33, https://doi.org/10.1080 /14672715.1971.10416250

${ }^{22}$ Long, "Vietnamese students and the center."

${ }^{23}$ Nguyen, "Antiwar Transnationalism."
} 
which intensified protests across the nation. One student, Ngo Thanh Nhan, stated that his own college courses discussed King at length through his books and essays. Others changed their opinions about the United States after speaking to American students about their experiences and perceptions of the war. Taking such classes, alongside viewing the U.S. involvement in Vietnam from an outsider's perspective, convinced most USAID students that the South Vietnamese government was merely an American puppet. $^{24}$

While not every student became ardent antiwar activists like Nguyen Thai Binh, many began to adopt more negative views of the American war in Vietnam. Several students Nguyen interviewed expressed that they were mortified about the violence occurring in Vietnam because of foreign interference. After their exposure to antiwar films and media, they became more convinced that Vietnam needed to be unified and not separated by Western interests. Others Nguyen spoke with, however, held different opinions. One particular interviewee, named $\mathrm{X}$, felt hesitant to repeat his activist activities if he were given a chance to go back in time. Unlike his companions, $\mathrm{X}$ believed that Vietnam would have benefited from a division like North and South Korea. Many other students did not respond to Nguyen's interview request. ${ }^{25}$

The mixed outcomes of the Leadership Scholarship program - and likely other informal student exchange programs under the auspices of the United States - points to the controversial nature of the war and its effects on the Vietnamese students in America. While some remained in the United States after their studies, others returned to Vietnam and continued to live their lives in the new Socialist Republic of Vietnam. A disclaimer posted to the students' website underscores the complexity of their experiences:

The rest of the story is still a debate as to how the war was lost or won, a war that left wounds so deep that have not healed after more than 30 years!). Many graduates came back and held important positions in the South Vietnamese government until the day Saigon fell (or liberated, depending who talks). A few of the students decided not to come home and sought residence in Canada, the US and Europe. Many of us have now settled in the US and all over the world. We call ourselves "USAID Leadership Students" for historical reasons. This Web Site is an attempt to create a communication channel so that the former USAID Leadership Students and their friends can share with one another stories of their lives and renew their special bonds. This site is not a political portal and it will not allow politics to be published or discussed. We encourage building friendship even with those of different political viewpoints. We encourage work that can help heal the wounds and bring better life to all Vietnamese in our former homeland.

The ambiguity surrounding the students' postwar lives mirrors the outcome of the war itself. The message's lack of political stance, or rather, refusal to take a stance, is indicative of the students' division

\footnotetext{
${ }^{24}$ Nguyen, "Antiwar Transnationalism."

${ }^{25}$ Ibid.
} 
over the war's ideology and its aftermath. While the tone of the website is mostly encouraging, the message also acknowledges the presence of wounds that have yet to heal, which suggests that pain was a major part of the participants' experiences. Pain, both emotional and physical, was inseparable from the war's long list of human costs. Nguyen Thai Binh, like others around him, would come to understand this pain clearly as his conversion from a neutral bystander to an antiwar activist initiated the beginning of a short but impactful activist career.

\section{Sit-In Rallies and Exceptional Risks}

As the turmoil of 1960s rolled into the next decade, the United States had already been at war in Vietnam for nearly five years. By that point, demonstrations had taken place all over America as citizens demanded an end to an increasingly indeterminate and costly conflict. President Richard Nixon continued the fight to uphold his image, but when the United States ventured into Cambodia, a nationwide student strike shut down over four hundred universities and colleges across the nation. ${ }^{26}$ The Kent State shooting on May 4, 1970, in which four unarmed student protestors were shot and killed by members of the Ohio National Guard, had begun as one of the student strikes. It was in this particular political climate that Nguyen Thai Binh seized his opportunity to join the cause, following the footsteps of other university students to arouse antiwar sentiment on his own campus.

In March 1968, shortly after the start of the Tet Offensive, Binh received a Leadership Scholarship from USAID to complete his undergraduate studies in the United States. After a year of study in Fresno, California, in the summer of 1969, he moved to Seattle to study at the Department of Fisheries Administration at the University of Washington. An honors student with exceptional records, Binh dedicated much of his time to speaking at antiwar rallies and attending sit-ins with other protesters. ${ }^{27}$ His overt presence as an activist at multiple university functions and political gatherings gestures to the significant role he played in challenging prowar attitudes about the American involvement abroad. Binh's early activism as an antiwar dissident dictated most of the events that occurred near the end of his life.

On June 24, 1971, Binh wrote a letter to the University of Washington (UW) newspaper The Daily to express his views on violence and war. In the first half of the letter, he referenced a statement from UW's Campus Crusader for Christ, Don Mansfield, who satirically questioned humanity's quest to achieve peace when violence is present all around. Mansfield stated that peace can be attained "simply by having it in your heart." In the bottom half of the letter, Binh responded to Mansfield's passive process of peacebuilding by insisting upon a more active and mobile resistance. He began by addressing the Christian themes in Mansfield's statement and affirming the contradiction of peace and violence, but then argued that Jesus Christ could not save the people of Vietnam, whose country the Americans were destroying. "No one," he asserted, "[can save them] except themselves." Binh further emphasized his call for resistance by penning an inscription at the bottom of the page in his own handwriting, that read, "My name is Thai Binh (PEACE). I am Vietnamese." ${ }^{\prime 28}$ His efforts to reconfigure the notion of passive

\footnotetext{
${ }^{26}$ Ryan Bergeron, “'The Seventies': Time’s Take on the End of Vietnam War,” CNN, Aug 17, 2015.

${ }^{27}$ Quoc Minh, "Giải Mã Hồ Sơ Nguyễn Thái Bình - Kỳ 2: Cảnh Sát Sài Gòn Đã Điều Tra Thế Nào?” Tuoi Tre Online, Jan $9,2018$.

${ }^{28}$ Nguyen Thai Binh letter to the University of Washington newspaper The Daily, Jun 24, 1971, Binh Memorial Collection.
} 
peacebuilding through an agitated letter foreshadows his future digression into active and high-risk antiwar activities.

On June 10, 1972, a month before his death, Binh delivered a commencement address at the University of Washington's graduation ceremony. Titled "Blood Debt," the address began with Binh's acknowledgement of the obligations he owed to the Vietnamese people. Unlike the many American students who were in financial debt at the university, Binh felt he owed "a debt of blood, bone, flesh of million Vietnamese" because he could study peacefully in America while those in his homeland suffered death and destruction. Binh's iteration of the war's casualties within the decade of direct American involvement in Vietnam was particularly resounding for its candidness. Using vivid prose, he explicitly described the millions of victims dead and injured, the thousands more driven from their homes, and the excessive bombing of the Vietnamese terrain, resulting in damaged crops, defoliated forests, and birth defects. Looking toward the graduating class of 1972, Binh asked that the students protest to end the war, calling it "barbaric, inhuman, immoral." Shortly after he began speaking, the police interrupted his speech and forcefully pulled him off the stage.$^{29}$ Although Binh had a considerable amount of time to deliver his manifesto, the authorities' subsequent actions indicate the controversial nature of his antiwar message.

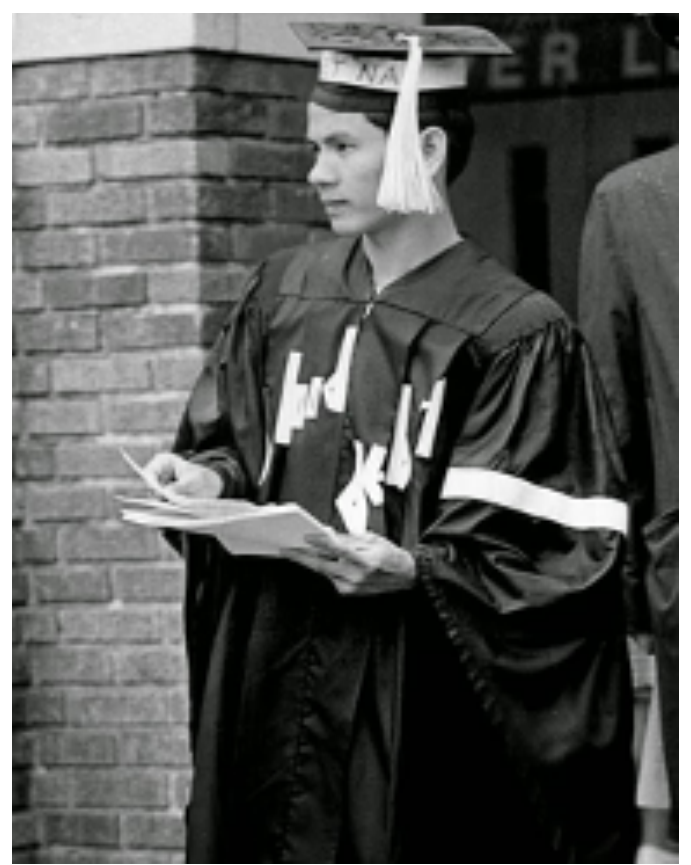

Figure 2. At his graduation, Nguyen Thai Binh passed out antiwar leaflets and graduation caps with anti-American slogans attached. University of Washington, May 26, 1972. Source: The Skies Belong to Us.

\footnotetext{
${ }^{29}$ Nguyen Thai Binh commencement address at the University of Washington, Jun 10, 1972, Binh Memorial Collection.
} 
In addition to his university-related activities, Binh also participated in larger government affairs. On March 29, 1972, he presented a speech for the Prisoner of War (POW) Ceremony at the Pentagon on the American involvement in the Vietnam War. Using the 1954 Geneva Accords as a reference, he accused the American government of repeatedly sabotaging the freedoms of the Vietnamese people. According to Binh's calculations, in the invasion of North Vietnam's air space by American pilots, pilots had released over half a million tons of bombs onto innocent children and people, killing thousands of civilians. To stress the United States' excessive violence and immorality, Binh emphasized the humanity of the Indochinese people. Nearly 1,600 American pilots were arrested as prisoners in North Vietnam after being shot down. Binh posited that the POW problem would continue as long as the war persisted, going so far as to justify the North Vietnamese government's inhumane treatment of American prisoners. He stated, to unenthusiastic audiences, that the Vietnamese government would release POWs if the American government withdrew its troops from Vietnam. ${ }^{30}$

Beyond his criticism of the U.S. military, Binh also excoriated the South Vietnamese government for its "barbaric measures" to limit discussion on the war in his country. ${ }^{31}$ At an antiwar rally in Seattle on April 19, 1972, Binh called on the audience to protest renewed American bombing, vehemently declaring, "I'm willing to take any risk. My responsibility is to the next generation of Vietnamese." Following the rally, he stated in a wire service interview that he expected the publicity around his name to prevent a "strong reaction" by the South Vietnamese government to his antiwar stance. ${ }^{32}$ His belief in the democratic protection of the press reveals his unwavering trust in the principle of free speech guaranteed under the U.S. Constitution.

Binh was not the only student who converted his beliefs after learning more about U.S. militarism in Vietnam during his studies. Along with nine other Vietnamese students studying in the United States at the time, Binh participated in the occupation of the South Vietnamese consulate in New York on February 10, 1972. The police arrested all ten students on charges of criminal trespassing after they forced their way into the consulate and staged a three-hour sit-in. A spokesperson said the students occupied the offices to call attention to their three demands: the immediate resignation of President Nguyen Van Thieu, the release of political prisoners, and an end to American involvement, which they argued was helping the Republic of Vietnam maintain its power by "terror and repression." 33 The students labeled the consulate's offices "a piece of our own property," thereby transforming their act of trespass into a sanctioned performance of property reclamation. Their identification as South Vietnamese students underscores this uniquely territorial act. Undoubtedly, their personal ties to the homeland directly fueled their strong opposition to the Saigon government.

\footnotetext{
${ }^{30}$ Nguyen Thai Binh statement for the P.O.W. Ceremony at the Pentagon, Mar 29, 1972, Binh Memorial Collection.

${ }^{31}$ Ngo Dinh Diem's stringent campaign to eliminate all negative criticism of the government during his presidency (1955-1963) trickled down onto the regimes that followed the 1963 coup d'état. In the attempt to curb all antiwar and pro-communist propaganda in the Republic of Vietnam, second president Nguyen Van Thieu (1967-1975) suppressed the country's freedom of speech and exacerbated previously repressive conditions. During his presidency, numerous newspapers were confiscated for echoing the people's voice. Writers and artists faced intimidation and imprisonment for their antiwar writing, their numbers contributing to the increase in prisons and detention camps. His tyrannical regime under Washington's management never gained civilian support, which eventually contributed to the government's downfall. U.S. Central Intelligence Agency, “Daily Report, Foreign Radio Broadcasts,” (Ohio State University Libraries, July 22, 1971).

${ }^{32}$ Vocal Antiwar Protester: Slain Viet Hijacker Identified as Honor Student in Seattle,” Los Angeles Times, Jul 03, 1972.

33 "10 Vietnamese Here Arrested at Sit-In," New York Times, Feb 11, 1972.
} 
Binh and a group of fifteen other Vietnamese also "invaded" the small Pennsylvania town of Carbondale to expose the government-sponsored Vietnamese Studies Center, which the students accused of being responsible for the training of repression agents in the Republic of Vietnam. ${ }^{34}$ On April 24, they staged a "Vietnamese Invasion of Carbondale" at Southern Illinois University (SIU) to protest the policies of the U.S.-backed Saigon government and SIU's controversial establishment. USAID, the very program to which many of the protestors belonged, backed the Vietnam Studies Center that provided training services to U.S. government agencies and offered technical support for "postwar reconstruction projects." "35 SIU's association with the war had been highly unpopular among Asian academic circles because of its similarity to the Michigan State University Vietnam Advisory Group's (MSUG) role in transitioning Vietnam from French colonialism to U.S. neocolonialism during President Ngo Dinh Diem's term. MSUG financially aided and helped to train individuals for Diem's secret police, as well as develop methods for Diem's repressive control. ${ }^{36}$ SIU's resemblance to MSUG only furthered the protestors' resistance to the organization's inception in Carbondale.

As Binh predicted, the South Vietnamese government reacted negatively to his antiwar activities. In retaliation, Saigon ordered seven of the ten students studying in the United States under grants from the U.S. Agency for International Development (USAID) to return home and face consequences for their critical views of the war and of President Nguyen Van Thieu's government. ${ }^{37}$ On June 7, Nguyen Thai Binh and three others, Nguyen Tang Huyen, Nguyen Huu An, ${ }^{38}$ and Vu Ngoc Con, received letters from Robert W. Landry, the deputy assistant training director for the development program. The letters informed them that their USAID-sponsored education had been terminated. Dated June 1, 1972, the letters added that airline tickets for transportation back to Vietnam were included and that the agency would kindly "assist" in their early return. Three other students - Doan Thu Nam-Hau, Bui Van Dao, and Tran Quoc Hung - received telephone calls from American officials notifying them of their academic suspension. They were then ordered to immediately return to Saigon at the request of the South Vietnamese government. ${ }^{39}$

All seven students refused to return to Vietnam, fearing the persecution they would face from President Thieu's regime. In explaining their unwillingness to relocate, the students cited a threat by Thieu to "beat to death" those of his countrymen who called for peace by willingly surrendering to the North Vietnamese communists. ${ }^{40}$ Fortunately for Binh and his fellow activists, the USAID administration found the letters to be administrative errors. Upon learning of the mistake, Maurice J. Williams, who was the deputy administrator for USAID, reported to the public that Landry's letters had been a departmental error and directed the agency to revoke the orders and permit the students to complete

\footnotetext{
${ }^{34}$ Le Anh Tu, "Death of a Hero," New York Times, Jul 21, 1972.

${ }^{35}$ Thi Nguyen, "Street Cred: Dauntless Antiwar Icon Nguyen Thai Binh and His Tragic Death," Saigoneer, Feb 18, 2020.

${ }^{36}$ Douglas Allen, "Universities and the Vietnam war: A case study of a successful struggle," Bulletin of Concerned Asian Scholars, vol. 8, no. 4 (1976): 2-16, doi:10.1080/14672715.1976.10404421

${ }^{37}$ While these seven recalled students were directly involved in the antiwar efforts taking place in America at the time, the other three unnamed students who participated in the occupation of the consulate in New York did not face similar consequences. The reasons behind their exclusion are currently unknown.

${ }^{38}$ Nguyen Huu An was an aviation engineering student who studied at the Northrop Institute of Technology in Inglewood, California. He received a letter from Binh before his friend embarked on the hijacking mission that would end his life (see introduction).

${ }^{39}$ Benjamin Welles, "7 South Vietnamese Students in U.S., Fearful, Refuse to Go Home,” New York Times, Jun $23,1972$.

${ }^{40}$ Ibid.
} 
their years. He added that USAID had erred in rescinding the students' stipends on the date of their termination. In acknowledgement of the error, Williams stated that all would receive checks to cover the rest of their stay in the United States. He went on to stress that the agency did not seek to stifle the freedom of expression nor the political activity of Vietnamese or other foreign students studying in the United States. ${ }^{41}$ This recalibration of integrity after the administration's error points to the wavering stances taken by American agencies toward curbing oppositional student activities.

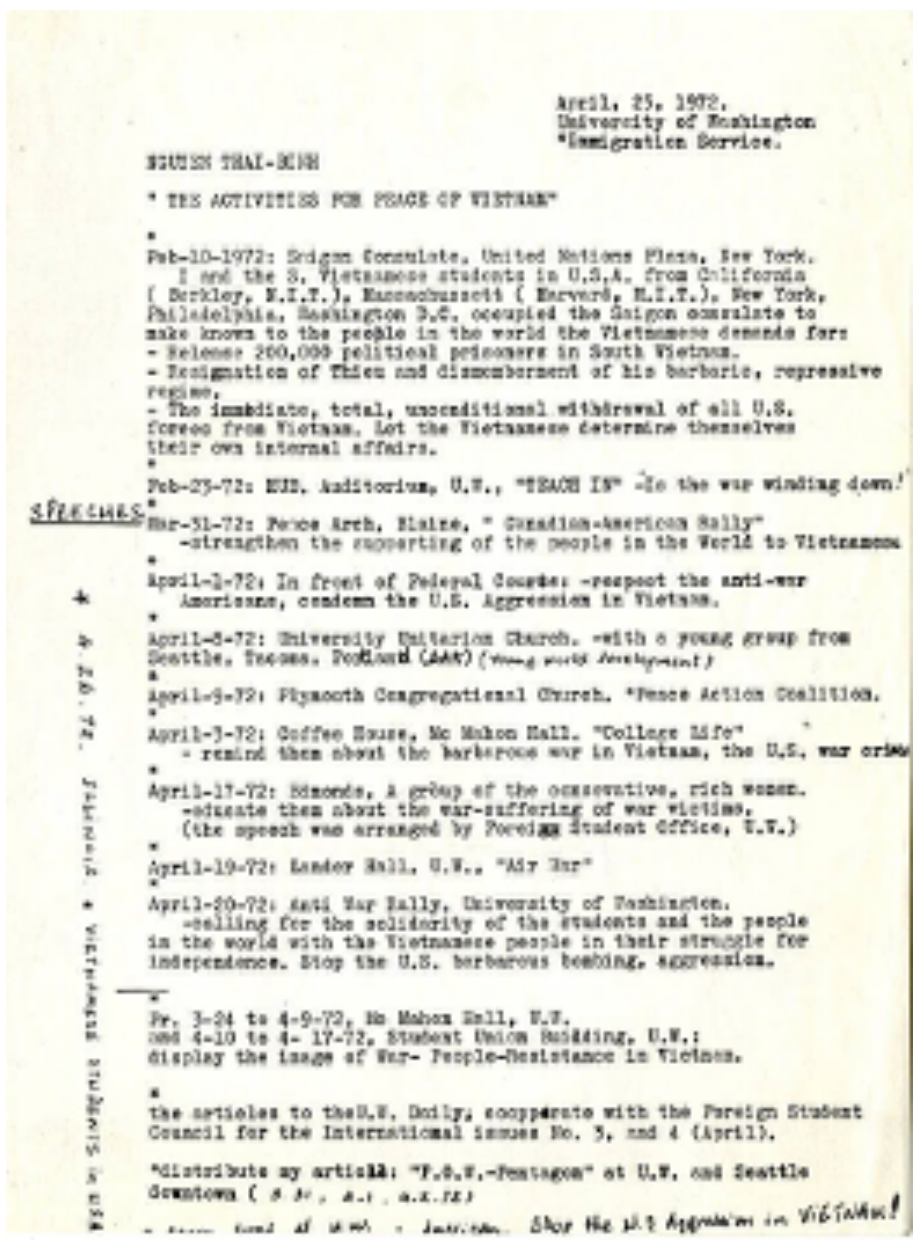

Figure 3. A flyer with listsed events that Binh and his friends organized from February to April in 1972. Source: University of Washington

Along with the South Vietnamese government's scrutiny, Binh faced questioning by U.S. immigration authorities for his antiwar activities. At the time of the Seattle rally, Binh had received a notice dated April 18, 1972, requiring him to appear for an interview with an immigration officer. Signed by Anthony Provenzo, the assistant district director of investigations, the notice stated the interview was "regarding your arrest in New York City on February 10, 1972, and present activities at the University of Washington." In the interview, Binh said that he had indeed occupied the South Vietnamese government 
offices in New York and had been arrested and charged with criminal trespass, but that the charges were later dropped. He then expressed that he felt further questioning on the matter would be improper. ${ }^{42}$ Aware of his unpopularity with the American government, Binh averted the inquiries that could potentially incriminate him and jeopardize his ability to continue his former activities.

The Vietnamese students' vociferous antiwar activities leading up to Binh's hijacking incident highlight the intensely personal connections the students had with their homeland. From letter writing to rallies and sit-ins, they employed their American freedom of speech to speak out against the government in radically visible ways. Their devotion to these acts of protest came with the understanding of their potential arrest and prosecution upon their return to South Vietnam. Despite the risks they incurred, the students upheld an unwavering commitment to peace, gambling their lives to stop a war they did not support.

Among his peers, Binh emerged as a natural leader. His persistent endeavors to achieve an improbable end revealed his unyielding sense of duty to the country of Vietnam. Conversely, his student life only demonstrated a small measure of how far he was willing to go to shift the American public's opinion. The threat of expulsion and the increased carpet-bombing of North Vietnam heightened Binh's fury in the spring of 1972. In a last-ditch effort to protest the war's progression, Binh resorted to an act of revenge that would ultimately end his life.

\section{Blood-Stained Notes and Football Tackles}

Although the year 1972 saw foreign involvement in South Vietnam gradually declining, the United States continued to bomb North Vietnam to compensate for its decreasing combat troops. In February, the U.S. Air Force conducted its then heaviest bombing raids of the war in attempt to disrupt an anticipated Easter Offensive. In March, an additional eighty-six U.S. air raids carried out in North Vietnam equaled the total number of raids against North Vietnam in all of 1971. President Nixon then authorized increased bombing of the troops belonging to the NLF in South Vietnam and B-52 strikes against North Vietnam in early April, unapologetically stating, "These bastards have never been bombed like they're going to be bombed this time." 43

The increased bombings of North Vietnam intensified Nguyen Thai Binh's anger. Unable to quell his overwhelming hatred, Binh decided he would "take care of the problem himself" and alerted a friend that he would be returning home. ${ }^{44}$

Before boarding the plane from San Francisco to Hawaii on July 1, 1972, Binh wrote an impassioned letter to the "peace and justice loving people in the world." Under the pseudonym Viet Thai Binh, he outlined the American military's committed atrocities in Vietnam to justify the dramatic actions he was about to take. During the Vietnamese struggle against the colonial French government in the 1940s and

\footnotetext{
42 "Vocal Antiwar Protester," Los Angeles Times.

${ }^{43}$ John S. Bowman, The World Almanac of the Vietnam War, (New York: Pharos Books, 1985), 298.

${ }^{44}$ Montgomery, "Hijacker Killed in Saigon."
} 
1950s, Binh recalled that the United States government had allied with the French by paying for nearly 80 percent of the French war cost. In addition, the U.S. government had used the 1954 Geneva Accords as "a smoke screen for its intervention and aggression, for its designs and crimes." Binh believed these actions supported the French colonialist regime and legitimized the U.S. government's violence against Vietnamese civilians in the American war. Binh saw only one clear path he could take to fight for the Vietnamese and end U.S. bombings on his country. In the letter, he wrote:

Going home to stand in the line of the Vietnamese people in the struggle of national salvation, to take part in the resistance against the U.S. aggression, to confirm the justness of our cause, to dedicate to the freedom fighters of Vietnam, living and dead, to strengthen the confidence in the eluctable victory of our people, I direct Pan Am 841 to Hanoi. I promise myself I shall not hurt any innocent person. ${ }^{45}$

True to his word, Binh resisted until the end of his own existence. When he departed Hawaii for Vietnam on the morning of July 2, 1972, he intimated in the letter to Nguyen Huu Anh that he felt a foreboding sense of doom, but his intuition could not have predicted the circumstances that would unfold on the flight back to his home country later that day.

The last piece of writing Binh conceived before his death was the threatening note he passed to Captain Gene Vaughn: "I am doing this for revenge. Your bombers are maiming and killing our people of the Democratic Republic of Vietnam. You are going to fly me to Hanoi and this airplane will be destroyed when we get there." 46 Given Binh's apprehension about returning to South Vietnam after criticizing the war and the Thieu government during his time in the United States, it is reasonable to believe that Binh diverted the plane to Hanoi to escape persecution and possible imprisonment under the Saigon regime.

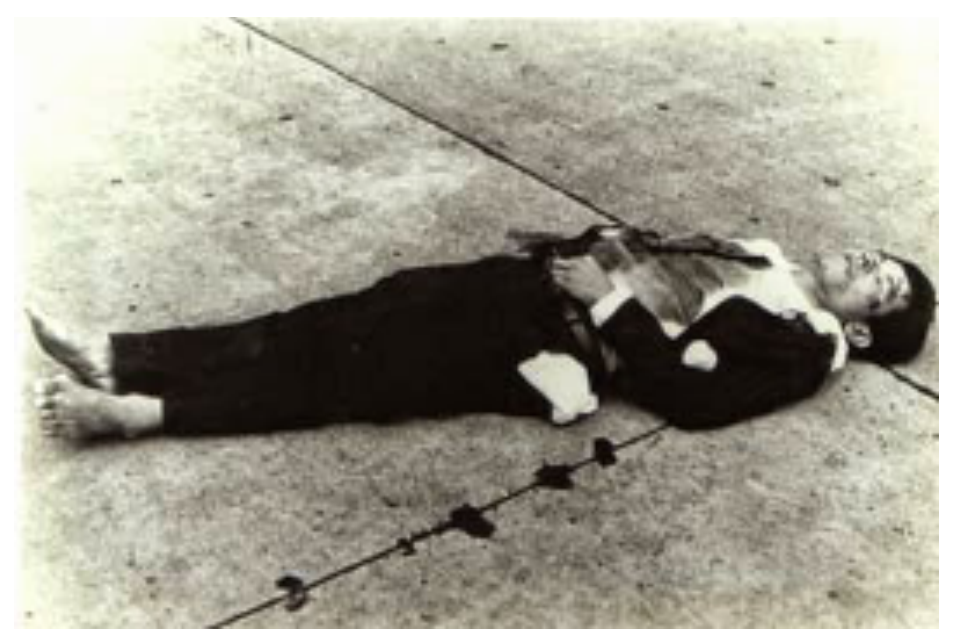

Figure 4. Dead body of Nguyen Thai Binh after his fatal shooting. Source: Minh Đức Blogspot.

\footnotetext{
${ }^{45}$ Viet Thai Binh open letter regarding resistance to the Vietnam War, Jul 1, 1972, Binh Memorial Collection. 46 “Passenger Shot Hijacker Five Times," Bangor Daily Newes, Jul 3, 1972.
} 
Binh carried a briefcase onto the Boeing 747 aircraft with sixty to seventy photographs of antiVietnam War demonstrations that had taken place in the United States, several of which were of events where he had been a speaker. According to the inflight director, William Wilcox, one of Binh's notes to the pilot stated that "vengeance was going to be wreaked because of what the Americans had been doing in Vietnam." Wilcox called the young antiwar activist a fanatic with "a wild look in his eyes." On the other hand, May Yuen, a flight attendant whom Binh held hostage briefly during his note-passing interim with the captain, described him as "a quiet man" who did not threaten her. Yuen even expressed that he was very nice to her and "did not mean to do anything rough." 47 The differences in these witness testimonies - one given by a white man and the other by a woman of color - suggest how race can play a role in the way certain people perceive the "enemy." Wilcox regarded Binh as a fanatical deviant, while Yuen emphasized his mild-mannered attitude despite her more vulnerable position.

An unnamed journalist for the Bangor Daily News described Nguyen Thai Binh as a "young Asian, apparently Vietnamese" who had threatened the captain of Pan Am Flight 841 in "fluent English." Captain Vaughn, the six-foot, two-hundred-pound pilot of the passenger carrier, initially ignored Binh's threatening notes and approached him when the plane landed in Saigon. Binh held a stewardess hostage and extended a long knife. Vaughn, pretending not to understand Binh's English from a distance, drew steadily closer until he could tackle the young man down to the ground. Vaughn then ordered the ex-cop passenger with the gun to shoot Binh. The man fired at Binh not once, but five times. After the killing, Captain Vaughn threw his dead body out of the rear exit, where it lay beside the plane on the concrete taxiway for more than an hour. ${ }^{48}$

Brimming with pride over his demonstration of physical prowess, Captain Vaughn narrated his version of Binh's murder to the press at a news conference later that night. According to Vaughn's own account, as Binh held the stewardess hostage and demanded for the plane to be rerouted to Hanoi, Vaughn sneaked up on him and "got a half-Nelson on his throat" and "could feel his neck collapsing." After the ex-policeman W.H. Mills, who was a passenger on the plane, shot Binh five times in the chest, Vaughn claimed he threw Binh's body out of the plane because "looking at that individual became so offensive I couldn't stand having him in the aircraft." Without hesitance, the captain admitted, "I got a good football hold on him and he went just like a football." 49 These words reimagine the Vietnamese body as a lifeless object suitable for the American aggressor to violently handle as indifferently as if it were a ball in a game of crude entertainment. This racial denigration relates back to Sylvia Chong's "oriental obscene," which highlights the pleasure derived from using the Asian body as a form and space for popular entertainment.

After his discussion of the incident, Vaughn proceeded to show the newsmen a live cartridge from the gun that killed Binh. The owner of the gun had given Vaughn the sole remaining cartridge as a souvenir. ${ }^{50}$ Vaughn's one-sided account of Binh's murder is sufficiently gory, but the overvaluation of the cartridge as a trophy item is indicative of deeper issues within the American psyche concerning race

\footnotetext{
${ }^{47}$ Ibid.

48 "Passenger Shot Hijacker," Bangor Daily News.

${ }^{49}$ Ibid.

50 "Passenger Shot Hijacker," Bangor Daily News.
} 
and violence. Unperturbed by the suggestive cruelty of the "souvenir," Vaughn, like many other white Americans involved in the war, gloated over his exhibition of power and racial domination.

The souvenir cartridge was not the only form of acclamation that Vaughn received. Upon the incident's news release, the Seattle Exchange Club commended him for ordering the fatal shooting of a man who had attempted to hijack an American plane. The Seattle flight operations manager accepted the crime prevention award on Vaughn's behalf, expressing that the airline "[was] very proud of Captain Vaughn." ${ }^{51}$ Days after, Vaughn bragged that his briefcase carried more than a hundred letters from people "expressing gratitude and appreciation that someone had stood up to a hijacker." 52 The public's deferential reception to Vaughn's violent actions demonstrates the predominantly racist sentiment within American society at the time, directed towards the Vietnamese for their likeness to the communist aggressor. Moreover, the American public's eagerness to celebrate Binh's fatal ending, calling him both an "air pirate" and a dangerous hijacker, suggests greater political aims to distort the revolutionary actions of Vietnamese students.

The racialized elements of the hijacking incident and the laudatory reception Vaughn received cannot be overlooked. The American people's celebration of Binh's inhumane death signifies the devaluation of a Vietnamese life, mirroring the atrocities occurring on the battlefront. Vaughn, in tackling Binh and pinning him to the ground, felt the situation was an offense to the human race," denigrating Binh to a mere anomaly who should be quickly destroyed. He then affirmed his xenophobic rhetoric by underscoring the necessity of a mandatory death penalty, "without any loopholes," for hijackers. ${ }^{53}$ If Binh represented the alien from abroad, discomfiting and offensive to American society, then Vaughn himself epitomized the death penalty he espoused, symptomatic of the American predilection to dispose of unwanted bodies of color.

Within days of the incident, Captain Vaughn returned to Scottsdale, Arizona to find his home completely vandalized. Animal intestines, paint, and broken bottles had been poured into his swimming pool, and an anonymous note was pinned to the diving board. Written in animal blood, the note stated: "Pig Eugene Vaughn guilty of murder. To be punished later. Long Live Nguyen Thai Binh. Victory to the Vietnamese. Death to the American aggressor." ${ }^{54}$ The note is indicative of community outrage after Binh's unexpected death. Although investigations never revealed the note's writer, the tendentious sentiment embedded within the paper's bloody writing hints at the unification of antiwar dissidents in reaction to the brutal incident. Vaughn told the press at a news conference that the note was "the reaction of sick people," but the cataclysmic resistance movement he incited from his violent act encompassed more than just a handful of ill-minded folks. ${ }^{55}$

\footnotetext{
51 "Fatal Order Wins Praise," Spokane Daily Chronicle, Aug 10, 1972.

52 "Pilot urges death penalty to curb airline hijackings," The Bulletin, Jul 7, 1972.

53 "Pilot urges death penalty," The Bulletin.

${ }^{54}$ Ibid.

55 “Note in Blood Threatens Life of Hijack Pilot," Lewiston Morning Newes, Jul 7, 1972.
} 


\section{Investigations and Legal Action}

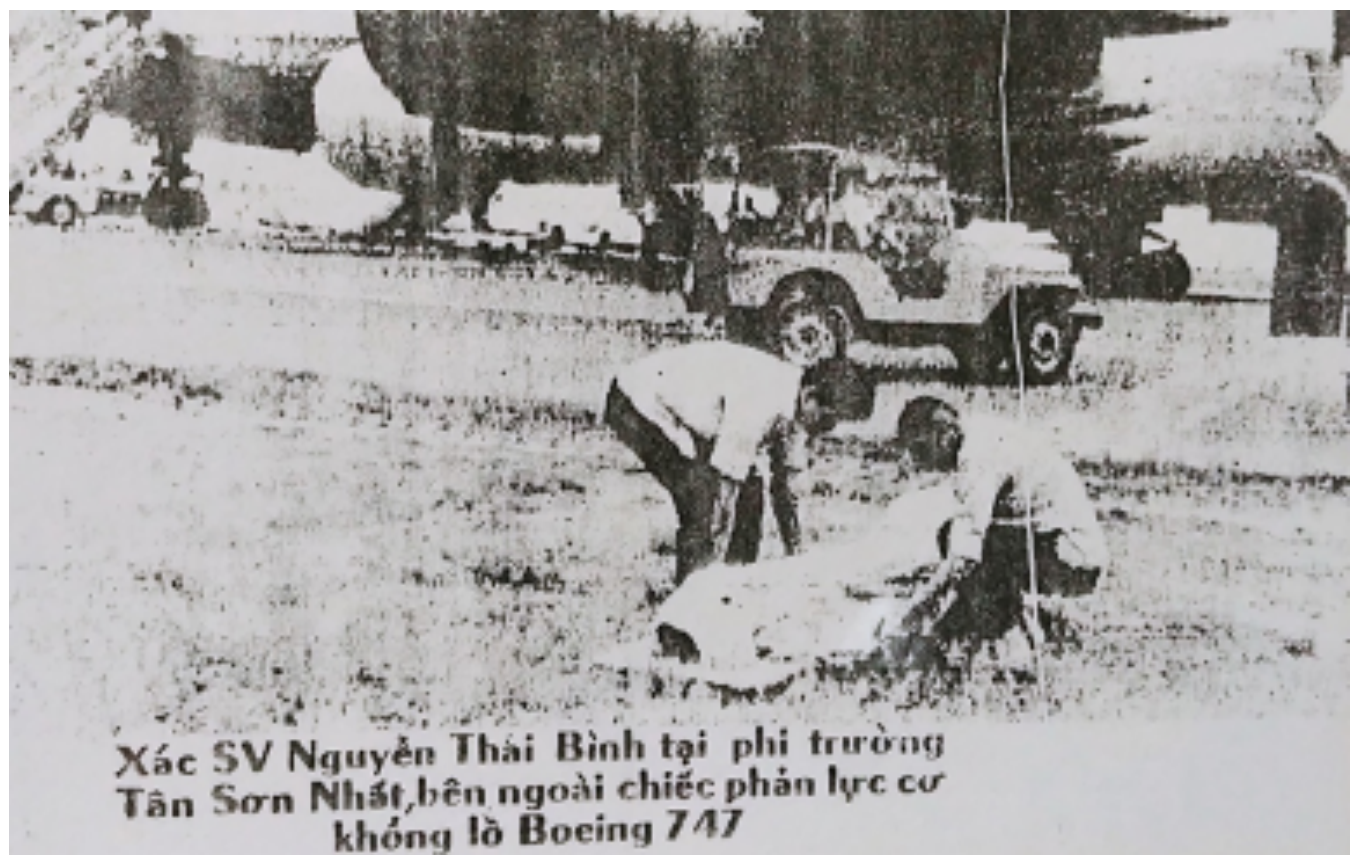

Figure 5. Saigon Press photo of the corpse of Nguyen Thai Binh being carried away by Saigon police. Source: Tuoi Tre Online.

Three different investigations into Binh's case revealed compelling evidence about his hijacking mission that conflicted with national headlines. The first report conducted by the Saigon Aviation Security Council looked into Binh's time as a student in America leading up to his death. During his studies in the United States, Binh had returned to Vietnam once on June 21, 1970 to renew his visa for a second term. However, when he embarked on Pan Am Flight 841 for his final journey home, he was not in possession of a visa issued by the U.S. Embassy. According to another report by Saigon police commander Nguyen Khac Binh, evidence from the incident confirmed that Binh did not threaten to kill any of the flight attendants nor did he possess explosive weapons. Binh had only torn Captain Vaughn's shirt with his knife in an attempt to free himself from the pilot's strangle, but at that exact moment the ex-police officer fired five gunshots into Binh's back. The evidence from the reports, which took nearly six months to gather, verified Binh's rebellious but otherwise benign protest. In light of these investigative records, perhaps the misrepresentation of Binh's activities in U.S. newspapers following his death was partly due to the lack of established evidence and also political aims to distort the revolutionary actions of Vietnamese students in America. ${ }^{56}$

In addition, one police report revealed that all three of the notes that Binh had coerced the flight attendant to pass to Captain Gene Vaughn had the initials NLF on the corner. ${ }^{57}$ This evidence intensified

\footnotetext{
56 “Giải Mã Hồ Sơ Nguyễn Thái Bình - Kỳ 2: Cảnh Sát Sài Gòn Đã Điều Tra Thế Nào? Decoding Nguyen Thai Binh's File - Part 2: How Did the Saigon Police Investigate?” Tuoi Tre Online, Jan 9, 2018.

${ }^{57}$ Ibid.
} 
problems for Binh's family in Vietnam. Hours following Binh's death, the Saigon government arrested his father, Nguyen Van Hai, and took his mother and sister into custody. The police refused to give any reason for their detention. Journalists attempted to locate Hai's whereabouts and spent two days searching for an explanation for his arrest. According to a New York Times report, "the National Police headquarters referred them to the Saigon police authorities who transferred them to the airport police, who said they had turned the case over to the National Police." ${ }_{58}$ The Saigon government's suspicion of Binh's family points to the intensification of repression under Thie's regime. In addition, the inexplicable nature of Hai's sudden arrest and the inorganized manner in which the Saigon police handled the case demonstrate the contentious politics behind Binh's hijacking and execution.

Binh's family, however, had not been aware of the circumstances or motivations leading up to Binh's hijacking. Days before his departure for Vietnam, Binh addressed a letter to Richard Carbray stating that if anything were to happen, Carbray should send Binh's writings, photos, and materials to his family "to make them understand the meaning of my sacrifice." ${ }^{59}$ For the last eight months of his life in Seattle, Binh had not been able to contact any of his family members due to restrictions imposed by the Saigon government. ${ }^{60}$ Given the lack of evidence to support the complicity of Binh's parents and siblings, the Saigon police's immediate reaction and arrest of the Nguyen family appears to be based on association alone.

Thomas J. Gumbleton, the Auxiliary Bishop of Detroit, addressed a letter dated July 11, 1972, to Senator Philip Hart's wife to request her help in guaranteeing the safety of Binh's surviving family. Binh had written a note to his former professor, Richard Carbray, whom he was very close to during his studies at the University of Washington, with the names and addresses of his family members in Saigon, entrusting Carbray with the information if anything were to happen to him. Carbray forwarded Binh's letter to the bishop and asked him for assistance in reaching out to higher authorities. Though Gumbleton never personally met Binh, he felt confident that "the kind of person he was is not manifest in the newspaper stories that have been written about the allegedly hijacking attempt." Furthermore, he expressed that Binh was a "loving and very serene and peaceful person." Gumbleton's opposition to the war, which he calls immoral within the letter, likely influenced his perception of Binh and his actions. Likewise, his efforts to aid Binh's surviving family members from imminent danger gesture to both the complexity of the case and Binh's prescient awareness of the potential threat to his family if he were to complete his hijacking mission. ${ }^{61}$

Later, the news revealed that Hai was being held at an interrogation center operated by the National Police's Special Branch, a semisecret organization often accused of using terror to extract information from prisoners. Furthermore, a lawyer associated with the case reported that Hai could be removed from standard criminal jurisdiction and held for as long as two years without trial under the state's Communist-suppression law. ${ }^{62}$ Though Binh's mother and sister eventually returned home, Binh's father remained in detention even after his son's funeral.

\footnotetext{
58 “Saigon Police Holding Father of Slain Hijacker," New York Times, Jul 17, 1972.

${ }^{59}$ Letter from Viet Thai Binh to Richard Carbray, June 30, 1972, Binh Memorial Collection.

${ }^{60}$ Letter from Viet Thai Binh to Richard Carbray, Jun 30, 1972, Binh Memorial Collection.

${ }^{61}$ Correspondence from Auxiliary Bishop Thomas J. Gumbleton to Mrs. Philip Hart, Jul 11, 1972, Binh Memorial Collection.

62 "Saigon Police Holding Father of Slain Hijacker," New York Times, Jul 17, 1972.
} 
The transfer of Binh's case from one Saigon police department to another underscores the complexity of the issue. The Aviation Security Council strongly condemned Captain Vaughn's unreasonable actions as an arbitrary execution. Yet, the council refused to handle the case as it "did not have sufficient authority."63 After receiving the report from the Council, the Saigon Prime Minister's Office expressed discontent with Vaughn, but declined to seek judicial action. In the end, the Saigon government chose not seek redress for Captain Vaughn's violation of aviation and diplomatic protocols despite the complaints of Binh's supporters and compatriots. ${ }^{64}$ The Nixon government did not respond to nor publicly acknowledge the hijacking incident either. ${ }^{65}$ It was not that Binh's case did not attract attention - it did. However, the sensitivity and reactionary nature of his death made both the Saigon and U.S. governments hesitant to handle the case in light of their tenuous and splintering relationship. The case was simply dropped.

On the other legal end, Binh's surviving family could not file a lawsuit against the pilot and Pan Am Airlines despite the incident's notoriety. An associate at Shim. Sigal. Ono \& Huddy responded to an inquiring letter from Mary Kaufman on the feasibility of defending Binh's lawsuit. Within the letter, the lawyer stated that the "potential for recovery is sufficient" for any attorneys to handle the matter on a small contingency fee. However, he believed the drawbacks to filing such a suit were far greater than any possible benefits of the desired outcome. The litigation expenses and depositions posed a problem, as well as the travel associated with these expenses, which could total more than two to four thousand dollars. The lawyer did not believe Binh's parents possessed enough money to advance the case. The lawsuit would also require an expert testimony to support a damage reward because the speculative nature of the case exposed its ambiguity and therefore, its unstable evidence. ${ }^{66}$

Furthermore, a considerable obstacle Binh's parents would have faced in filing a major lawsuit was the possibility of "interference" by the Saigon government. The regime could forbid Binh's lawyer from entering Vietnam to prevent his parents' depositions, and "Saigon hostility to the parents might be such as to be the negative factor in their willingness to assert...their legal rights to recovery." ${ }^{67}$ The culmination of these disadvantages may explain why Binh's parents sought no legal action following their son's murder. Their lack of money, inability to travel, and possible confrontation with the Saigon government likely unraveled any advancements in Binh's incipient lawsuit. Moreover, the lawyer's response to Kaufman's inquiry reveals the writer's deeper concern with potential "political problems" if American attorneys chose to intervene in the controversial matter.

Many activists and Vietnamese groups continued to gather to remember Binh and his efforts days, weeks, and even years after the hijacking incident. Although there had been no distinct and cohesive Vietnamese antiwar group prior to his death, Binh's fatal mission charged Vietnamese students in

\footnotetext{
63 “Saigon's National Police Department to Saigon Prime Minister's Office, Dec 5, 1972," as quoted in Nguyet Nguyen, "Antiwar Transnationalism."

${ }^{64}$ According to a letter written by Mr. Do Van Du to Richard Carbray, most newspapers in Saigon as well as the people "felt sorry for Binh" and saw him as a very intelligent and brave man who was willing to perform extreme deeds for his family and country. While this does not indicate whether his supporters were aware of his NLF-leanings, it shows that Vietnamese in Saigon were compassionate towards Binh's motivations to end the war. Letter from Do Van Du to Richard Carbray, Jul 6, 1972, Binh Memorial Collection.

${ }^{65}$ Nguyen, "Antiwar Transnationalism."

${ }^{66}$ Letter from Attorney to Mary Kaufman, Aug 15, 1972, Binh Memorial Collection.

${ }^{67}$ Ibid.
} 
America, Asian Americans, and other cultural antiwar groups to protest against the U.S. government. Their organizing resisted the mainstream commendation for Vaughn and opened critical dialogue on the treatment of non-white lives. The memorials and commemorations that followed permanently engraved Binh's legacy into history.

\section{One Nation Under Protest}

In Can Giuoc, a rice-farming town in the Mekong Delta, Nguyen Thai Binh's mother and siblings buried him in his place of birth on July 6, 1972. A hearse arrived at the family's home and drove his casket to the grave site. From there, fifteen pallbearers, dressed in the uniform of the Rural Development cadre, carried the casket through a graveyard surrounded by rice fields. A Buddhist monk prayed as Binh's mother and sisters wept. A small choir sang mournfully. Binh's siblings, dressed in all white, stood around his grave bearing pictures of Binh during his time as a student at the University of Washington. ${ }^{68}$

A number of individuals and antiwar groups assembled in various ways following the hijacking incident to protest what they believed to be the unjust assassination of a Vietnamese innocent. Through letters, rallies, and memorial services, they highlighted the systematic oppression they endured as people of color in the United States and linked the growing antiwar movement to the sacrifice of innocent lives for peace. The unprecedented unification of Vietnamese students in support of an antiheroic figure both emphasized the severity of the hijacking episode and enhanced their visibility in the antiwar effort. ${ }^{69}$

Following Nguyen Thai Binh's death, President Richard Nixon received a letter from Ms. Le Thi Anh, Binh's heartbroken mother. She wrote that the Nguyen family was thankful to the United States for allowing her son to study at the University of Washington for his degree, but that she was shocked to find out he was shot and killed on his return to Vietnam. Her imagery is particularly poignant when she stated, "But, the day he returned he was but a corpse without a soul, with 5 bullet holes in his chest and bearing the label of 'air pirate'." Thi Anh's grievance illuminates the repercussions of Binh's death on his immediate family. She expressed doubt that her son could have hijacked the plane and pretended to have a bomb with him. Moreover, she contended that "the murder of my son was planned in advance, perhaps an assassination" and hypothesized that the retired cop who shot Binh conspired with the pilot to shoot him. Thi Anh implored President Nixon to investigate the incident further, calling upon his character and position as "the leader of the free world" to bring justice to Binh and his family. ${ }^{70}$

\footnotetext{
68 "Binh lies among rice fields: 'He always put family first," The Seattle Times, Jul 6, 1972. Binh Memorial Collection.

${ }^{69}$ Richard Carbray had written a letter to Gloria Emerson, a famous journalist and wartime correspondent for The New York Times. She responded on June 20,1977, with a curt letter stating that she knew the name Nguyen Thai Binh and pasted the photograph giving the dates of his life over her desk. She admitted that she "could not go back to the Times" and stopped being a reporter to take the position of political editor for The Rolling Stones. Emerson's letter is intriguing because of her analysis of the effects of war and the antiwar movement on her own well-being. She stated, "Working so hard in the anti-war movement, put me in a very lonely zone and even now, even now, the pain and the dreams are with me." Although Emerson's connection to Binh is unclear, she was clearly traumatized by his death and the events that led up to it. As sensationalized as the hijacking was, Binh's actions reached beyond his college campus to important antiwar figures in the movement. Response letter from Gloria Emerson to Richard Carbray, Jun 20, 1977, Binh Memorial Collection

${ }^{70}$ Mrs. Le Thi Anh letter to President Nixon regarding the death of her son, Nguyen Thai Binh, Jul 17, 1972, Binh Memorial Collection.
} 
As Ms. Le Thi Anh's letter suggests, Binh's family had a hard time grappling with the reality of his death. They did not believe that Binh was capable of hijacking a plane. At his funeral, Binh's cousin claimed that "no one in the family believes [he] was trying to hijack a Pan American jumbo jet." None of the pictures his siblings held around his grave showed Binh speaking or protesting at antiwar rallies. There are two possible reasons behind this suspension of belief. First, the family believed Binh's actions were inconsistent with his peaceful and studious demeanor, and to hijack an American plane was to renounce his South Vietnamese ties which had gained him a Leadership Scholarship to study in the United States in the first place. Second, Binh's family did not want to be associated with a communist sympathizer. In the interview, his cousin wished for the press and public opinion to clear up the matter because the continuing accusations would cause "shame for the family."72 Knowing that Binh could not contact his family during his most prolific period of activism, the family's inability to believe the hijacking is plausible.

Binh's close friends also responded to the incident in critical ways. Le Anh Tu, a fellow activist and a good friend, commented on the hijacking in a letter to the editor of The New York Times. In it, she stated: "No Vietnamese would question his sacrifice." Written on July 4, 1972, Anh Tu drew connections between the United States' Independence Day and the Vietnamese struggle to liberate themselves from the Western colonizer and American oppressor. By referencing how the early colonialists resisted King George's rule, she called on the American public to empathize with the similar struggle happening in Vietnam and understand "how much we hate your Government's domination of our people."'73

Beyond friends and family, strangers who championed Binh's resolve and felt angered by his death spoke out in support. The Asian Coalition was a coalition of Asian Americans committed to resisting against the war in Indochina. They produced the New York Asian Coalition Newsletter to state their beliefs on the war's morality, stressing that "the war against the Indochinese peoples is the most barbaric and repressive in the history of mankind." In solidarity, these Asian Americans empathized with Southeast Asians in their ongoing struggle for self-determination and colonial liberation. Recognizing the military-industrial complex rooted within the United States, the coalition pledged themselves in full support of the Indochinese people and demanded the complete withdrawal of all American troops from Vietnam. In a newsletter published in July 1972, the Asian Coalition emphasized that its members held the U.S. armed forces responsible for the "genocide" of the Vietnamese people. The newsletter also included a statement regarding Binh's death, painting the announcement in aggressive words that stressed the violent injustices committed by the U.S. military and government on Vietnam. The coalition's intentional use of the terms "genocide" and "martyr" underscores the radicality of Binh's renegade mission to essentially "save" the Vietnamese people from mass murder. Unlike the progressive Americans who resisted the war away from the battlefield, Binh saw himself within the frontline struggle and therefore fought for the Vietnamese in his own fatalistic ways. His zeal for peace - and death in its antithetical violence - consequently labeled him as martyr for the antiwar cause, which pushed him to the forefront of the Asian Coalition's resistance movement.

\footnotetext{
71 “Slain Viet Hijacker Buried by Family," Seattle Post-Intelligencer, Jul 7, 1972, Binh Memorial Collection.

${ }^{72}$ Ibid.

${ }^{73} \mathrm{Tu}$, "Death of A Hero."
} 
The Vietnamese antiwar movement was not a cohesive unit until after Binh's death. The Union of Vietnamese in the United States (which later became the Association of Vietnamese in the United States) was formed by Vietnamese student activists in USAID Group II after the news of Binh's murder. ${ }^{74}$ Although the organization began in California colleges and universities, it eventually grew into a national leftist organization with multiple campus chapters nationwide. This group supported the peace program of the NLF and was a vital component of early 1970s antiwar efforts. Following the end of the war, the Union sought to end the U.S. embargo on Vietnam and eventually dissolved after the normalization of U.S.-Vietnam diplomatic relations in $1995 .^{75}$

Ngo Thanh Nhan was a founding member of the Union of Vietnamese and became one of its first Standing Committee members. Like Binh, Nhan had received a Leadership Scholarship from USAID in 1968 to complete his studies in the United States but gradually became disillusioned with the war in Vietnam. After his political conversion, he was deeply involved with the small Vietnamese community in San Jose where he attended school. Although there was no report of Vietnamese in the U.S. census at the time because of their low population (>2000), Nhan and his fellow activists studied numerous Vietnamese communities all over California and recruited members from major cities around the country to join their protest against the war. By 1972, he and other Vietnamese student organizers, most of whom were fellow USAID students, were starting to discuss ways to help end the war. Binh's death was the catalyst for the official formation of the Union. Angered by the catastrophic event, smaller groups across the United States joined together to support the NLF's seven-point peace plan and finish Binh's vision. ${ }^{76}$

The Union of Vietnamese consisted of Binh's peers and fellow antiwar activists, as well as Vietnamese married to American G.I.s, USAID students, other students at different campuses, and Vietnamese soldiers in the United States for training purposes. ${ }^{77}$ Most of the participants believed in the same principles as Binh had and continued his fight despite the danger they could potentially face. Nguyen Dong, a member of the Union, wrote a letter to Binh's former professor Richard Carbray on April 5, 1973, in an envelope with the Union's propaganda posters concerning "the arrival of the Union to this country." Binh had been a mutual friend of Dong and Carbray. In the letter, Dong shared that he had received an assistantship in Oregon but feared that his scholarship would end at any time because he was too "noisy." His fear echoes the USAID's erroneous dismissal of Vietnamese students for their antiwar activities on UW's campus. Despite this, Dong insisted that Carbray distribute the posters enclosed with the letter to anyone he considered favorable. The first poster enclosed within the envelope, titled "Thieu is coming!", denigrates President Nguyen Van Thieu for his administrative blunders and implores "the American people" to recognize the fraud, murders, and money-laundering in Thieu's repressive regime. The poster also criticizes the United State' interference and financial assistance in

\footnotetext{
${ }^{74}$ Tram Quang Nguyen, "Caring for the Soul of Our Community: Vietnamese Youth Activism in the 1960s and Today," Asian Americans: The Movement and the Moment, ed. Steve Louie and Glenn Omats (Los Angeles: UCLA Asian American Studies Center Press, 2001), pp. 285304.

${ }^{75}$ Ngo Thanh Nhan, "Union of Vietnamese in the United States," in Many Bridges, One River: Organizing for Fustice in Vietnamese American Communities, ed. thuan nguyen and Vy Nguyen (Los Angeles: UCLA Asian American Studies Center Press, 2017), 3. Nhan,

76 "Union of Vietnamese in the United States."

${ }^{77}$ Ibid.
} 
Vietnam as a tactic to keep Thieu in power. The bottom blurb of the poster reads, "SHOULD WE, THE AMERICAN PEOPLE, STAKE OUR NATIONAL HONOR ON WELCOMING HIM TO THIS COUNTRY?" The reference to national honor paints a visible and looming threat to America's public image, which encourages viewers to question the vulnerability of their country to disreputable figures. ${ }^{78}$

The Union held a memorial service for Binh on July 16, 1972 as one of the organization's first joint actions. The Black Panther Party in Oakland had heard the news of Binh's death and joined hands with the Union members to conduct the ceremony. ${ }^{79}$ The members and Binh's supporters organized a candle march to demand an end to the U.S. government's support of the Thieu regime, the exposure of Binh's murder to the people of Vientam, the immediate release of Binh's family by the Thieu government, ${ }^{80}$ and a terminal date for the withdrawal of U.S. forces and those of its allies. ${ }^{81}$ With white bands wrapped around their foreheads, the Union and Black Panther Party members marched past the Pam Am office building in downtown San Francisco with a large sign that read, "The Union of Vietnamese in the U.S. Commemorates Nguyen Thai Binh" (see Figure 5). Those in attendance spent the whole night without sleep in honor of Binh. Their collaboration is one example of the cross-cultural and interracial exchanges that occurred as a result of Bin's posthumous legacy. After the joint action, the Union continued to form more alliances with other activist groups from different racial and ethnic backgrounds by including Asian American, Iranian, Palestinian, and Latinx communities. ${ }^{82}$

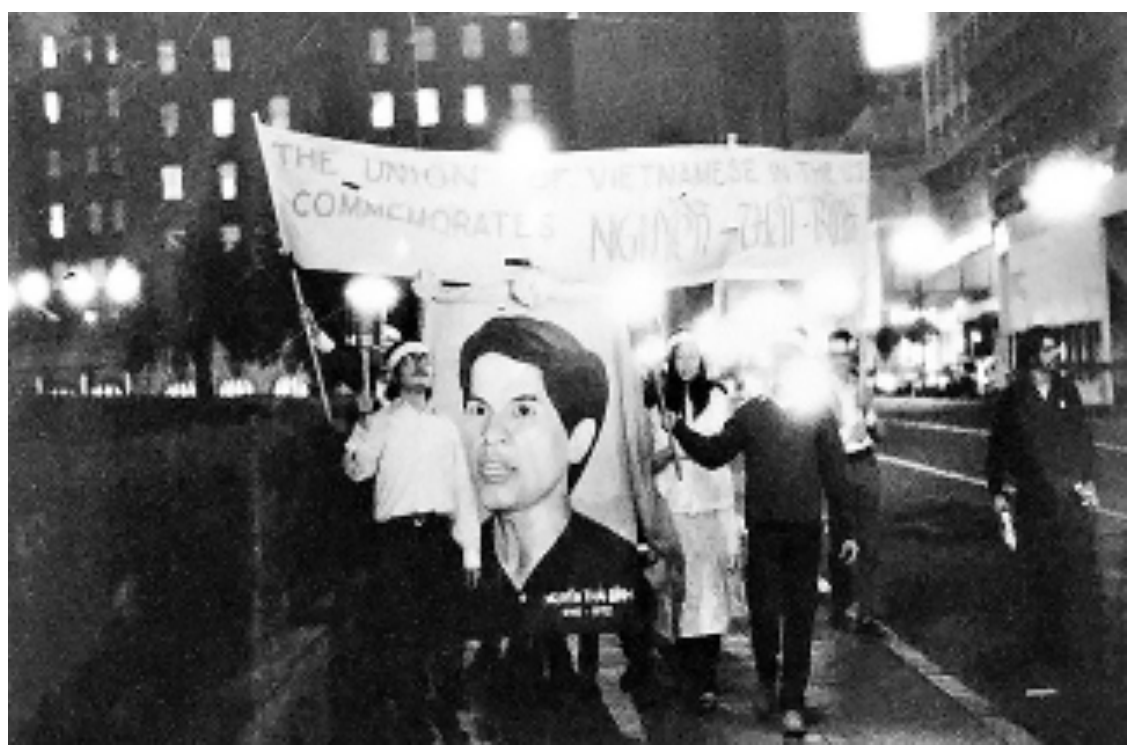

Figure 6. Demonstration by the Union of Vietnamese following Nguyen Thai Binh's death. Source: Tuoi Tre Online.

\footnotetext{
${ }^{78}$ Letter from Nguyen Dong to Richard Carbray, Apr 5, 1973, Binh Memorial Collection.

${ }^{79}$ Tram Nguyen, "Caring for the Soul of Our Community."

80 "Saigon Police Holding Father of Slain Hijacker," New York Times.

${ }^{81}$ The Union of Vietnamese in the United States Commemorates Nguyen Thai Binh, Jul 16, 1972, The Freedom Archives.

${ }^{82}$ Nguyen, "Street Cred."
} 
After the Union of Vietnamese formed, it grew quickly in membership and activities. The organization's mission was twofold. Within the antiwar movement, the members advocated for the Vietnamese people's self-determination from foreign imperialists and colonizers. Within the Vietnamese community, they promoted the patriotic vision of a free and independent Vietnam. For the latter, the Union began publishing a magazine called Thai Binh to inform the Vietnamese in America about what was happening inside Vietnam, as many were not aware of the realities of the conflict in their homeland. ${ }^{83}$ From 1972 until 1975, all of the Union members protested the American involvement, often side by side with the Vietnam Veterans Against the War, a group of American veterans who had turned against the war by marching together in a peace demonstration in $1967 .{ }^{84}$ They also had the support of other progressive cultural groups. Asian and African Americans joined together with the Union to form a central committee that combined small local groups into chapters in the Bay Area, Los Angeles, and New York. Together, they formulated ideas on how to combat the war effort and assist the national antiwar movement. ${ }^{85}$

The Union also faced heavy opposition to their activities on multiple fronts. As a result of their radical and anti-government beliefs, the Federal Bureau of Investigation (FBI) and the U.S. government closely monitored their interactions and threatened to deport several key members of the organization. In South Vietnam, many of the participants were tried for "treason in absentia," which would result in an immediate execution if they were to return. ${ }^{86}$ According to Nhan, who luckily remained in the United States and later became a university professor, the Saigon Embassy revoked the students' passports, and the United States followed by withdrawing their visas. Seven of these students were tried in immigration court and nearly deported. With the help of antiwar lawyers, the students continued their stay in the United States. Another oppositional force came from Vietnamese in America who were vehemently anti-communists. Most of the people who belonged in this group came to the United States for military training and a college education like the USAID student activists, but they adhered to their original convictions and casted Union members as traitors and Viet Cong affiliates. While there was no violence nor malicious activity between the prowar and antiwar factions, group debates occurred on TV programs over the pros and cons of the American involvement. ${ }^{87}$

Aside from the Union of Vietnamese's commemoration for Binh, other memorial ceremonies also took place within weeks of his death. On July 14, 1972, the Asian Coalition and several Vietnamese students sponsored Nguyen Thai Binh's memorial service at the United Nations Church Center in New York City. The memorial itself was a student protest against Binh's murder and the war in Vietnam. The print flier for the service read: "'My only bomb is my human heart.' With these words another Vietnamese gave his life." The reference to "my only bomb" acknowledges the misperception of

\footnotetext{
${ }^{83}$ Nhan, "Union of Vietnamese in the United States."

84 "Vietnam Veterans Against the War," VVAW, vvaw.org.

${ }^{85}$ Nhan, "Union of Vietnamese in the United States."

${ }^{86}$ Ibid.

${ }^{87}$ After the war in 1975, however, Vietnamese arrivals in America led to increased hostility between the Union members and anticommunist refugees. Right-wing Vietnamese groups targeted Union members with violence for their "communist activities" and labeled them as dissidents. Many assassinations occurred as a result.
} 
Binh's dangerous "lemon" explosives on the hijacked plane. Beneath the title, the flier stated, "A time to remember. A time for commitment." Alluding to the notion of commitment honors Binh's fight for unified resistance, as he often stressed that Asians should bind together to defeat the common enemy. ${ }^{8}$

The memorial service quickly took on the form of a rally for peace and justice. The program flier included a poem and a scheduled reading of Binh's letter to President Nixon. Titled "Blood Debt," the poem honored Binh's antiwar spirit by charging the "dark force of U.S. imperialism" for the murder of thousands of Vietnamese and Asians around the world. Written by a "Korean Brother," it signified the solidarity formed between Asians and Asian Americans because of Binh's death. The poem suggests that their unification at the memorial was not only to remember Binh, but to also continue the struggle for self-determination and freedom, the principles for which Binh fought. Likewise, a statement by the Asian Coalition affirmed, "His sacrifice does not dishearten us, but rather inspires us to redouble our efforts to actively support the liberation struggle of all Indochinese people." These words encapsulate the form of solidarity that Binh strived to achieve when he was still alive. As if a crowd spoke in unison, a line at the bottom of the page declared, "Victory to the people of Indochina!"89

Later that fall, a group of 150 Asian American high school students marched in honor of Nguyen Thai Binh and Van Troi (another Vietnamese martyr) at the 1972 Nisei Week parade in California. They called themselves the Thai Binh Brigade. Their joint statement read, "We are a group of young Asian brothers and sisters who have united to show opposition to the genocidal war being waged by the U.S. government against the Southeast Asian people, and to show our love and support to the just struggle of our Vietnamese cousins." As their statement suggests, Asian Americans across the United States felt deeply angered by Binh's untimely and cruel death, but they were also inspired by his radical actions to avenge the people of Vietnam. ${ }^{90}$ The Thai Binh Brigade and Van Troi Brigade marched the streets and burned the Rising Sun flag to demonstrate their opposition to militarism and Japanese profiteering during the war.

Non-Asians also joined in on the remembrance effort. On July 5, 1972, an antiwar group consisting of white American students held a mock funeral in Miami Beach for Binh. The protesters left quietly after the police refused to let them place a piece of plywood strewn with hibiscus flowers in a canal as a part of the "funeral." ${ }^{91}$ However, their efforts to commemorate Binh's actions with a funeral gesture to the deep impact he left on the American community at large. Though Binh is not a remembered figure in the history books, he was a cherished student and activist among those honored his legacy. Every year for nine years after Binh's death, his friends and teachers at the University of Washington gathered to memorialize him.

\footnotetext{
${ }^{88}$ Asian Coalition \& Vietnamese Students, “In memorium Nguyen Thai Binh, 1948-1972," Jul 14, 1972, Binh Memorial Collection.

${ }^{89}$ Nguyen Thai Binh'xs memorial service program, Jul 14, 1972, Binh Memorial Collection.

${ }^{90}$ Lily Eng, "Honoring a Young Life that Ended Too Soon-20 Years Later, Friends Still Saddened," Seattle Times, Jul 3, 1992.

91 "Mock Funeral for Hijacker," The New York Times, Jul 5, 1972.
} 


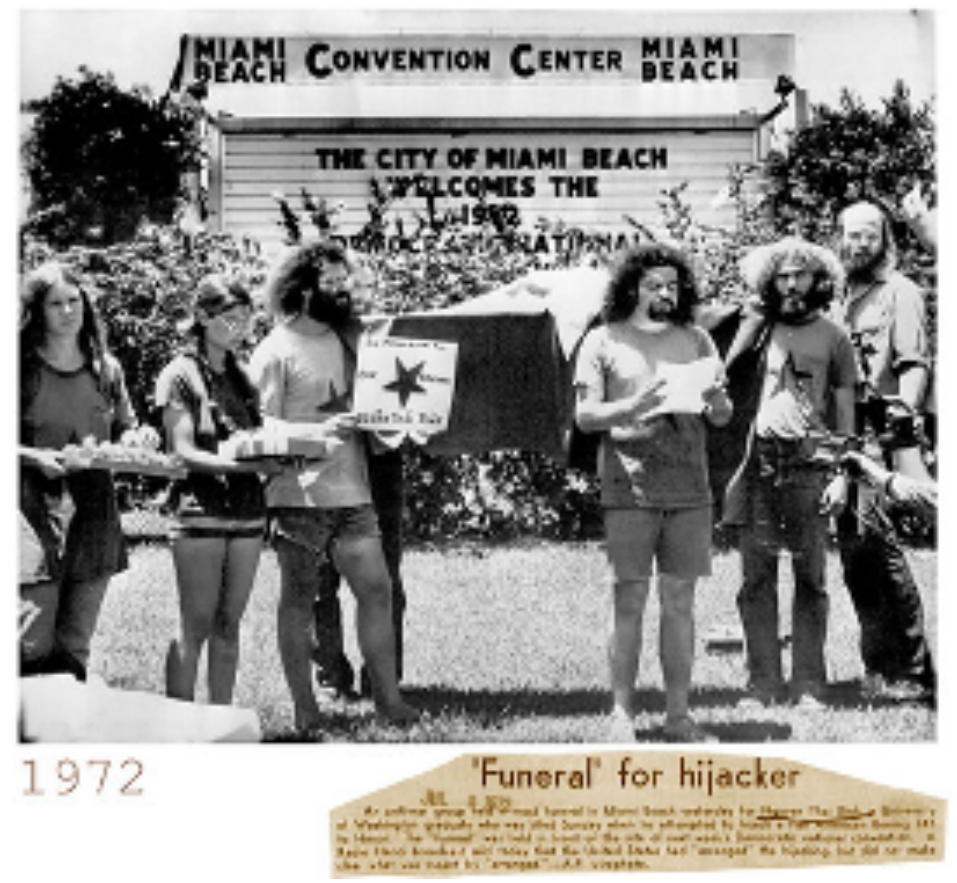

Figure 7. An anti-war group organized a funeral for Nguyen Thai Binh in the Miami Beach Convention Center. Source: Flickr.

In 1992, the last memorial was held in Seattle to mark the twenty-year anniversary of Binh's death. In contrast to the major newspapers, which described him to be dangerous and irrational, his college professors and friends knew him as a peace activist who wrote poetry, but also boxed and played soccer. ${ }^{92}$ In 2010, the Socialist Republic of Vietnam awarded Binh the title of "Hero of the People's Army Forces in Vietnam" for his antiwar activities as a student in the United States. Today, one can find Binh's lasting impact in former Saigon, where the Vietnamese have memorialized him with his very own Nguyen Thai Binh Street. ${ }^{93}$

\section{Conclusion}

In his own way, Nguyen Thai Binh challenged the institutional racism and militarism of the war in Vietnam and compromised his good standing with the South Vietnamese government to speak out against the war and President Thieu's regime. Although his account is merely one snapshot among other important narratives of Vietnamese students who rallied against the war, Binh's dying devotion to his cause demonstrates the lengths to which Vietnamese antiwar activists could go to resist what they perceived to be a destructive and intolerable war in their home country.

\footnotetext{
${ }^{92}$ Eng, "Honoring a Young Life."

${ }^{93}$ Ron Jacobs, "Ho Chi Minh City: Nguyen Thai Binh Street," CounterPunch.org, Apr 19, 2019. https://www.counterpunch. org/2019/04/19/ho-chi-minh-city-nguyen-thai-binh-street/.
} 
In his own way, Nguyen Thai Binh challenged the institutional racism and militarism of the war in Vietnam and compromised his good standing with the South Vietnamese government to speak out against the war and President Thieu's regime. Although his account is merely one snapshot among other important narratives of Vietnamese students who rallied against the war, Binh's dying devotion to his cause demonstrates the lengths to which Vietnamese antiwar activists could go to resist what they perceived to be a destructive and intolerable war in their home country.

The cross-cultural alliances built across racial and ethnic boundaries transformed Nguyen Thai Binh's singular mission to exact revenge into a wider acknowledgement of the value of Vietnamese lives. Although he died in a grim manner, the varied reactions to his death marked the differences between white Americans who supported the war and marginalized groups who saw the conflict as a personal affliction upon their own bodies. Likewise, Captain Gene Vaughn's treatment of Binh's body offers us an orientalist critique of how Americans perceive and receive satisfaction from its fantastical yet abusive adaptation of modern entertainment.

In the broader context of the war, the Vietnamese antiwar movement was not significant for its scale - there were not many Vietnamese in the United States at the time - but rather for its double critique of race and nationhood. Situated within the larger picture of Asian American politics, the movement questioned the motivations behind U.S. involvement in Vietnam and highlighted the bloodshed and brutalities occurring on the frontlines to Vietnamese bodies. It also confronted issues of self-determination, which had been a core element of the Vietnamese postcolonial struggle for independence since the 1954 Geneva Accords. Like Binh, Vietnamese antiwar activists in America both moved and negotiated their spaces as bicultural dividers, particularly in using their American freedom of speech to demand for peace back home. Their insider perspectives on both American and Vietnamese cultures differentiate them from other antiwar activists rooted solely in the United States, allowing them to view the war as both racially charged and inhumane on personal grounds. While historians have often excluded the narratives of Vietnamese activists from the historical memory of the American antiwar movement, their inclusion is important for understanding how antiwar transnationalism redefined notions of identity, belonging, and race across national boundaries. 


\section{Works Cited}

\section{Primary Sources}

"10 Vietnamese Here Arrested at Sit-In.” New York Times, February 11, 1972.

http://library.tcu.edu/PURL/EZproxy_link.asp?https://search.proquest.com/docview/1192 72636?accountid=7090. Accessed November 20, 2019.

Asian Coalition. "New York Asian Coalition Newsletter." August 1972, Accession no. 2242001, Box 1/1, Binh Memorial Collection, Pacific Northwest Historical Documents, Special Collections Libraries, University of Washington. https://digitalcollections. lib.washington.edu/digital/collection/pioneerlife/id/20687/.

Asian Coalition \& Vietnamese Students. "In memorium Nguyen Thai Binh, 1948-1972." N.d., Accession no. 2242-001, Box 1/1, Binh Memorial Collection, Pacific Northwest Historical Documents, Special Collections Libraries, University of Washington. https://digitalcollections.lib.washington.edu/digital/collection/pioneerlife/id/20698/rec/2.

Bergeron, Ryan. "'The Seventies': Time's Take on the End of Vietnam War." CNNN, August 17, 2015. https://www.cnn.com/2015/06/23/living/the-seventies-time-magazine-vietnamwar/index.html. Accessed November 18, 2019.

"Binh lies among rice fields: 'He always put family first."” The Seattle Times. Jul. 6, 1972. Binh Memorial Collection, Box 1/20, Pacific Northwest Historical Documents, Special Collections Libraries, University of Washington.

Correspondence from Auxiliary Bishop Thomas J. Gumbleton to Mrs. Philip Hart, Jul 11, 1972. Binh Memorial Collection, Box 1/1, Pacific Northwest Historical Documents, Special Collections Libraries, University of Washington.

Eng, Lily. "Honoring A Young Life That Ended Too Soon - 20 Years Later, Friends Still Saddened." Seattle Times, July 3, 1992. http://community.seattletimes.nwsource.com/ archive $/$ ?date $=19920703 \&$ slug $=1500312$. Accessed November 29, 2019.

"Fatal Order Wins Praise." Spokane Daily Chronicle, August 10, 1972. https://news.google.com/ newspapers?id=VrozAAAAIBAJ\&sjid=oPgDAAAAIBAJ\&pg=2599,2953406. Accessed November 10, 2019. 
"Giải Mã Hồ Sơ Nguyễn Thái Bình - Kỳ 2: Cảnh Sát Sài Gòn Đã Điều Tra Thế Nào? Decoding Nguyen Thai Binh's File - Part 2: How did the Saigon Police Investigate?" Tuoi Tre Online, Jan 9, 2018. https://tuoitre.vn/giai-ma-ho-so-nguyen-thai-binh-ky-2-canh-sat-sai-gonda-dieu-tra-the-nao-2018010911475675.htm.

Jacobs, Ron. "Ho Chi Minh City: Nguyen Thai Binh Street.” CounterPunch.org, April 19, 2019. https://www.counterpunch.org/2019/04/19/ho-chi-minh-city-nguyen-thai-binh-street/.

"Kill Vietnamese Hijacker Carrying Lemon 'Bombs'." The Daily News, July 3, 1972. https://news.google.com/newspapers?id=_kAKAAAAIBAJ\&sjid=LEoDAAAAIBAJ\&pg $=6123,54839$. Accessed November 11, 2019.

"Leadership Scholarship." http://www.leadershipstudents.org/Relatives/faq.htm. Accessed April $24,2020$.

Letter from Do Van Du to Richard Carbray, Jul. 6, 1972. Binh Memorial Collection. Box 1/1. Pacific Northwest Historical Documents, Special Collections Libraries, University of Washington.

Letter from Viet Thai Binh to Richard Carbray, June 30, 1972, Binh Memorial Collection. Box 1/3. Pacific Northwest Historical Documents, Special Collections Libraries, University of Washington.

"Long An Province Pays Tribute to Hero Nguyen Thai Binh.” Saigon-GP Daily, May 1, 2013. https://sggpnews.org.vn/national/long-an-province-pays-tribute-to-hero-nguyen-thaibinh-56002.html. Accessed November 11, 2019.

Minh, Quoc. "Giải Mã Hồ Sơ Nguyễn Thái Bình - Kỳ 2: Cảnh Sát Sài Gòn Đã Điều Tra Thế Nào?” Tuoi Tre Online, January 9, 2018. https://tuoitre.vn/giai-ma-ho-so-nguyen-thaibinh-ky-2-canh-sat-sai-gon-da-dieu-tra-the-nao-2018010911475675.htm. Accessed December 9, 2019.

"Mock Funeral for Hijacker," The New York Times, July 5, 1972. https:/ /www.nytimes.com/ 1972/07/05/archives/mock-funeral-for-hijacker.html. Accessed November 20, 2019.

Montgomery, Paul L. "Hijacker Killed in Saigon; Tried to Divert Jet to Hanoi." The New York Times, July 3, 1972. https://www.nytimes.com/1972/07/03/archives/hijackerkilled-in-saigon-tried-to-divert-jet-to-hanoi-south.html. Accessed October 2, 2019. 
Mrs. Le Thi Anh letter to President Nixon regarding the death of her son, Nguyen Thai Binh. July 17, 1972, Accession no. 2242-001, Box 1², Binh Memorial Collection, Pacific Northwest Historical Documents, Special Collections Libraries, University of Washington. https://digitalcollections.lib.washington.edu/digital/collection/ pioneerlife/id/20699/rec/3.

Nguyen Thai Binh letter to Nguyen Huu An regarding his flight home to Vietnam. July 3, 1972, Accession no. 2242-001, Binh Memorial Collection, Box 3/6, Pacific Northwest Historical Documents, Special Collections Libraries, University of Washington. https://digitalcollections.lib.washington.edu/digital/collection/pioneerlife/id/20702/

Nguyen Thai Binh's memorial service program. July 14, 1972, Accession no. 2242-001, Box 1/3, Binh Memorial Collection, Pacific Northwest Historical Documents, Special Collections Libraries, University of Washington. https://digitalcollections.lib.washington.edu/digital/collection/pioneerlife/id/20700/rec/5.

Nguyen Thai Binh commencement address at the University of Washington. June 10, 1972, Accession no. 2242-001, Box 3/9, Binh Memorial Collection, Pacific Northwest Historical Documents, Special Collections Libraries, University of Washington. https://digitalcollections.lib.washington.edu/digital/collection/pioneerlife/id/20703/rec/2

Nguyen Thai Binh statement for the P.O.W. Ceremony at the Pentagon. March 29, 1972, Accession no. 2242-001, Binh Memorial Collection, Pacific Northwest Historical Documents, Special Collections Libraries, University of Washington. https://digitalcollections.lib.washington. edu/digital/collection/pioneerlife/id/20707/rec/4.

Nguyen Thai Binh letter to the University of Washington newspaper The Daily. June 24, 1971 , Accession no. 2242-001, Box 3/9, Binh Memorial Collection, Pacific Northwest Historical Documents, Special Collections Libraries, University of Washington. https://digitalcollections.lib.washington.edu/digital/collection/pioneerlife/id/20706/rec/3.

Ngo, Nhan Thanh. "Union of Vietnamese in the United States." In Many Bridges, One River: Organizing for Fustice in Vietnamese American Communities, edited by thuan nguyen and Vy Nguyen, 3-13. Los Angeles: UCLA Asian American Studies Center Press, 2017.

"Note in Blood Threatens Life of Hijack Pilot." Lewiston Morning News, July 7, 1972. https://news.google.com/newspapers?id=wqFfAAAAIBAJ\&sjid=FDIMAAAAIBAJ\&pg =6447,1223813. Accessed October 6, 2019. 
"Passenger Shot Hijacker Five Times." Bangor Daily News, July 3, 1972. https:/ /news.google .com/newspapers? id=0Cic0AAAAIBAJ\&sjid=5eAIAAAAIBAJ\&pg=620530723 Accessed October 2, 2019.

"Pilot Urges Death Penalty to Curb Airline Hijackings." The Bulletin. Google News Archive Search. Google. July 7, 1972. Accessed November 10, 2019. https://news.google.com /newspapers?id=tgg0AAAAIBAJ\&sjid=v_cDAAAAIBAJ\&pg=4769\%2C6642778

Report by Tan Son Nhat's Airport Security Committee, Phủ thủ tướng [Prime Minister Collection], \#31069, Trung tâm Lưu trũ Quốc gia II [National Archives II], HCMC. Quoted in Nguyet Nguyen, "Antiwar Transnationalism: People's Diplomacy in the Vietnam War.” PhD Dissertation, American University, 2019. ProQuest Dissertations Publishing (22585339). http://library.tcu.edu.ezproxy.tcu.edu/PURL/EZproxy_link.asp?/login?url=https:/ / search-proquest-com.ezproxy.tcu.edu/docview/2276075888?accountid=7090.

Response letter from Gloria Emerson to Richard Carbray, June 20, 1977. Binh Memorial Collection, Box 1/1, Pacific Northwest Historical Documents, Special Collections Libraries, University of Washington.

“Saigon's National Police Department to Saigon Prime Minister's Office, Dec 5, 1972.” Quoted in Nguyet Nguyen, “Antiwar Transnationalism: People’s Diplomacy in the Vietnam War." PhD Dissertation, American University, 2019. ProQuest Dissertations Publishing (22585339). http://library.tcu.edu.ezproxy.tcu.edu/PURL/EZproxy_link.asp?/login?url=https:/ / search-proquest-com.ezproxy.tcu.edu/docview/2276075888?accountid=7090.

"Saigon Police Holding Father of Slain Hijacker.” New York Times, July 17, 1972. http://library.tcu.edu/ PURL/EZproxy_link.asp?https://search.proquest.com/docview/119513693?accountid=7090. Accessed October 29, 2019.

"Slain Viet Hijacker Buried by Family," Seattle Post-Intelligencer, Jul. 7, 1972. Binh Memorial Collection, Box 1/20, Pacific Northwest Historical Documents, Special Collections Libraries, University of Washington.

The Union of Vietnamese, "The Union of Vietnamese in the United States Commemorates Nguyen Thai Binh," The Freedom Archives, July 16, 1972. https://search.freedomarchive s.org/search.php?view_collection $=253 \&$ keyword $\% 5 B \% 5 \mathrm{D}=$ Nguyen + Thai + Binh\&title $=\mathrm{T}$ he+Union+of+Vietnamese+in+the+United+States+Commemorates+Nguyen+Thai+Binh . Accessed October 20, 2019. 
Tu, Le Anh. "Death of a Hero.” New York Times, July 21, 1972. https://search.proquest.com docview/119571194?pq-origsite=summon. Accessed October 2, 2019.

U.S. Central Intelligence Agency. "Daily Report, Foreign Radio Broadcasts." Ohio State University Libraries, July 22, 1971. https://tinyurl.com/y4qsm36s. Accessed November 9, 2019.

Viet Thai Binh open letter regarding resistance to the Vietnam War. July 1, 1972, Accession no. 2242-001, Binh Memorial Collection, Box 1/4, Pacific Northwest Historical Documents, Special Collections Libraries, University of Washington. https://digitalcollections.lib.washington.edu/ digital/collection/pioneerlife/id/20683/rec/1.

"Vocal Antiwar Protester: Slain Viet Hijacker Identified As Honor Student In Seattle." Los Angeles Times, Jul 03, 1972. https://search.proquest.com/docview/157175256?pq-origsite=summon\&accountid $=7090$.

Welles, Benjamin. "7 South Vietnamese Students in U.S., Fearful, Refuse to Go Home.” New York Times, Jun 23, 1972. http://library.tcu.edu/PURL/EZproxy_link.asp? https://search.proquest.com/docview/119406098?accountid=7090.

\section{Secondary Sources}

Allen, Douglas. "Universities and the Vietnam war: A case study of a successful struggle."

Bulletin of Concerned Asian Scholars, vol. 8, no. 4 (1976): 2-16, https://doi.org/10.1080/14672715.1 976.10404421.

Bowman, John S. The World Almanac of the Vietnam War. New York: Pharos Books, 1985.

Chong, Sylvia Shin Huey. The Oriental Obscene: Violence and Racial Fantasies in the Vietnam Era. Durham [N.C.]: Duke University Press, 2012.

Ishizuka, Karen L. Serve the People: Making Asian America in the Long Sixties. London: Verso, 2016.

Koerner, Brendan I. The Skies Belong to Us: Love and Terror in the Golden Age of Hijacking. New York: Broadway Books, 2014.

Ngo, Vinh Long. "Vietnamese students and the center." Bulletin of Concerned Asian Scholars, vol. 3, no. 2 (1971): 32-34, https://doi.org/10.1080/14672715.1971.10416250. 
Nguyen, Nguyet. “Antiwar Transnationalism: People’s Diplomacy in the Vietnam War.” PhD Dissertation, American University, 2019. ProQuest Dissertations Publishing (22585339). http://library. tcu.edu.ezproxy.tcu.edu/PURL/EZproxy_link.asp?/login?url=https://search-proquest-com. ezproxy.tcu.edu/docview/2276075888?accountid=7090.

Nguyen, Thi. "Street Cred: Dauntless Antiwar Icon Nguyen Thai Binh and His Tragic Death." Saigoneer, Feb 18, 2020. https://saigoneer.com/eat-drink/147-ads/18331-street-cred- nguyen-thai-binh's-promise. Accessed Apr 24, 2020.

Nguyen, Tram Quang. "Caring for the Soul of Our Community: Vietnamese Youth Activism in the 1960s and Today." Asian Americans: The Movement and the Moment, ed. Steve Louie and Glenn Omatsu. Los Angeles: UCLA Asian American Studies Center Press, 2001. 285-304.

Nguyen, Y. Thien. "(Re)Making the South Vietnamese Past in America.” Journal of Asian American Studies 21, no. 1 (2018): 65-103. https://muse.jhu.edu/article/685881

"Vietnam Veterans Against the War." VVAW, n.d., www.vvaw.org. 